\title{
“DON QUIJOTE DIO SU ESPÍRITU, QUIERO DECIR QUE SE MURIÓ”. CLAVES DE LA MENTALIDAD TANÁTICA BARROCA CASTELLANA
}

\author{
Máximo GARCÍA FERNÁNDEZ \\ Universidad de Valladolid
}

RESUMEN: El Quijote es una 'metáfora de la vida como teatro' (y del 'sueño de la vida') al presentar las ‘culturas y cosmovisiones del Barroco'. Modelo que significa la aceptación final de su papel espectacular y de toda la lección barroca del desengaño ante la muerte.

Por eso, tras el estudio del testamento de Don Quijote se analiza el complejo significado de la agonía popular a través de la literatura (moral, novela o sátira) y la pintura de la época para comprender mejor las claves barrocas de aquella religiosidad colectiva castellana. De la misma forma que el impacto público de las honras fúnebres regías reafirmaba colectivamente la mentalidad contrarreformista. Las visiones de diferentes viajeros extranjeros también muestran, críticamente, la sacralización vital castellana imperante durante el largo siglo XVII.

En suma, resultaba capital el control de la muerte y la 'búsqueda de solidaridades en el más allá', mediante un complejo y variado ritual funerario. La Iglesia controlaba aquellos miedos mediante un amplio sistema de méritos sacralizados. Y todavía las respuestas a un cuestionario de 1901 muestran el mantenimiento de los ritos sobre "prevención, agonía, entierro, prácticas mortuorias, cementerios y culto a los muertos”.

PALABRAS CLAVE: Don Quijote, Barroco, Castilla, Mentalidad popular, Muertes y funerales.

ABSTRACT: Don Quichot is a 'metaphor of life as a theatre' (and of 'the dream of life') showing the culture and the world view of the baroque period. This model implies the final acceptance of the impressive role of Don Quichot and of the hard baroque lesson of confronting death.

For this reason, after studying the testament of Don Quichot, this article will focus on the complex significance of popular agony through literature (moral, novels, satires) and painting of the period, in order to better understand the baroque keys of the collective religiosity of Castile. In the same manner, the public impact of the honorary royal funerals, reaffirmed the collective mentality of the CounterReformation. The different opinions of foreign travellers also reflect, in a critical way, the sacralisation of life in Castile during the Seventeenth Century.

In conclusion, control of death through a complex and varied array of funeral rituals was essential together with the 'search for solidarity in the hereafter'. The Church controlled the fears of the population through a whole system of sacralised merits. Even the answers to a 1901 questionnaire show the continuity of the rites on 'prevention, agony, burial, mortuary practices, cemeteries and the cult of the death'.

KEYWORDS: Don Quichot, Baroque, Castile, Popular mentality, Deaths and funerals. 
Siglos atrás, y en concreto en el XVII, el "juego de las contradicciones” lo invadía todo: esperando un "ingenuo retorno a lo real". El "irrealismo español”, y con una desvinculación total de la cotidianeidad, "prefería soñar" leyendo a Góngora, a Lope, la segunda parte del Guzmán de Mateo Alemán o El Quijote ${ }^{1}$ "Ha llegado el tiempo en que España se confronta con sus mitos, para reír o para llorar... y del naufragio de un mundo y de sus valores surge una genial tragicomedia, una obra maestra que fija en imágenes sus contrastes”, resumió acertadamente Pierre Vilar. "¡Y que se queje quien le duela!”; a ese "hombre encantado que vive fuera del orden natural”, según Cellórigo, en 1605, Cervantes le dio un nombre inmortal ${ }^{2}$.

\section{TESTAMENTO Y MUERTE DE DON QUIJOTE}

En el último capítulo de la famosa obra cervantina se encuentra el Testamento de don Quijote y su muerte. Allí se narran sus cuitas finales. Muchas de las aventuras de tan singular novela reflejan a la perfección la mentalidad sacralizada de aquella sociedad castellana de los siglos XVI y XVII, con sus comportamientos, actitudes, miedos y ritos funerarios. Así, numerosas expresiones recuerdan las fórmulas que solían encabezar los testamentos, los acompañantes necesarios a la cabecera del moribundo y las recomendaciones que para prepararse bien para una 'buena y santa muerte' hacían aconsejable redactar las últimas voluntades, rodearse de amigos (más que de familiares) y de clérigos intercesores antes que de los médicos o arrepentirse de los pecados mediante la confesión, el viático y la extremaunción. Algunos de sus párrafos explican nítidamente la religiosidad colectiva y popular de la época ${ }^{3}$.

"Como las cosas humanas no son eternas, yendo siempre en declinación de sus principios hasta llegar a su último fin, especialmente las vidas de los hombres, y como la de don Quijote no tuviese privilegio del cielo para detener el curso de la suya, llegó su fin y acabamiento cuando él menos lo

${ }^{1}$ Véanse: Franco RuBIo, G. (2004). Cultura y mentalidad en la Edad Moderna. Sevilla; Bouza Álvarez, F. (1990). Religiosidad, contrarreforma y cultura simbólica del Barroco. Madrid; y Feros, A. y GelABerT, J. E. (dirs.) (2004). España en tiempos del Quijote. Madrid.

A este respecto, los trabajos del profesor Maravall siguen siendo fundamentales. Véase: José Antonio Maravall, J. A. (1986). La cultura del Barroco. Análisis de una estructura histórica. Barcelona.

${ }^{2}$ Vilar, P. (1980), “El tiempo del Quijote”. En Crecimiento y Desarrollo. Barcelona, pp. 332346.

3 Cervantes SaAvedra, M. de (1998). El ingenioso hidalgo don Quijote de la Mancha. Barcelona (Valladolid (1605); 'De cómo don Quijote cayó malo y del testamento que hizo y su muerte', II, LXXIV. 
“Don Quijote dio su espíritu, quiero decir que se murió”. Claves de la mentalidad tanática barroca castellana

pensaba; porque por la disposición del cielo, que así lo ordenaba, se le arraigó una calentura que le tuvo seis días en la cama, en los cuales fue visitado muchas veces del cura, del bachiller y del barbero, sus amigos, sin quitársele de la cabecera Sancho Panza. Todos procuraban alegrarle y llamaron al médico. Tomole el pulso y no le contentó mucho, y dijo que, por sí o por no, atendiese a la salud de su alma, porque la del cuerpo corría peligro; su ama, su sobrina y su buen escudero comenzaron a llorar tiernamente, como si ya le tuvieran muerto delante. Melancolías y desabrimientos le acababan”.

“ ¡Bendito sea el poderoso Dios que tanto bien me ha hecho! Sus misericordias no tienen límite, ni las abrevian ni impiden los pecados de los hombres".

"Yo [don Quijote] conozco los disparates y embelesos [de los libros de caballerías] y no me pesa sino que este desengaño ha llegado tan tarde que no me deja tiempo para hacer alguna recompensa. Me siento, sobrina, a punto de muerte: querría hacerla de tal modo, que diese a entender que no había sido mi vida tan mala que dejase renombre de loco, confirmando esta verdad en mi fin. Llámame a mis buenos amigos, que quiero confesarme $y$ hacer mi testamento".

"Siento que me voy muriendo a toda priesa: tráiganme un confesor que me confiese y un escribano que haga mi testamento, que en tales trances no se ha de burlar el hombre con el alma; y, así, suplico que en tanto que el señor cura me confiesa vayan por el escribano”.

"Una de las señales por donde conjeturaron se moría fue haber vuelto con tanta facilidad de loco a cuerdo y añadir otras muchas cristianas razones. Acabose la confesión y salió el cura diciendo: 'verdaderamente se muere cuerdo; bien podemos entrar para que haga su testamento'”.

Esto hizo "reventar a todos las lágrimas de los ojos y mil profundos suspiros del pecho”. "Entró el escribano, y después de haber hecho la cabeza del testamento y ordenado su alma, don Quijote, con todas aquellas circunstancias cristianas que se requieren, llegando a las mandas dijo: item, es mi voluntad...”. Tras el encabezamiento (siempre muy católico -con introducción religiosa: protestación de fe, encomendación del alma, señalización del lugar de sepultura, hábito mortuorio y número de misas a celebrar por su salvación- y atendiendo a los requisitos legales), era costumbre continuar con las cuestiones económicas (fijando los legados testamentarios y nombrando albaceas -en este caso, el señor cura y el bachiller Sansón Carrasco- y herederos), y así lo hizo también el ingenioso hidalgo, pues "vámonos poco a poco, y ya en los nidos de antaño no hay pájaros hogaño: yo fui loco y ya soy cuerdo”. Tras abonar sus deudas mandó pagar a Sancho Panza 
todos los atrasos, dados sus merecimientos y fidelidad, y sin que se le pidiese cuenta alguna, "aunque será bien poco, buen provecho le haga, y perdóname amigo" "“no se muera vuestra merced, no sea perezoso y viva muchos años, porque la mayor locura que puede hacer un hombre en esta vida es dejarse morir sin más ni más", rezaba el agradecido escudero), lo mismo que el salario de su ama "más veinte ducados para un vestido"; para disponer acto seguido que toda su hacienda recayese en manos de su sobrina Antonia Quijana ("habiendo sacado primero de lo más bien parado della [de lo que se dispusiese más fácilmente] lo que fuere menester para cumplir las mandas que dejo hechas"), aunque con una interesante cláusula coercitiva final: ésta lo perdería todo en el caso de que se casase con alguien que supiese de 'libros de caballerías', distribuyéndose entonces todo su importe en obras pías, a voluntad de sus dos albaceas (a quienes también encargaba y suplicaba que apercibiesen caritativamente al autor de la segunda parte de estas hazañas "porque parto de esta vida con escrúpulos"). "Cerró con esto el testamento, y se tendió en la cama”.

" $Y$ en tres días que vivió después se desmayaba muy a menudo. Andaba la casa alborotada, pero, con todo, comía la sobrina, brindaba el ama y se regocijaba Sancho, que esto del heredar algo borra o templa en el heredero la memoria de la pena que es razón que deje el muerto [la alegría de la herencia es templanza del dolor funerario]. En fin, llegó el último de don Quijote, después de recibidos todos los sacramentos [preparatorios para una buena muerte] y después de haber abominado con muchas y eficaces razones de la caballería... ningún caballero andante había fallecido en su lecho tan sosegadamente y tan cristiano. El cual, entre compasiones y lágrimas de los que allí se hallaron, dio su espíritu: quiero decir que se murió”.

Murió tranquilamente, en la cama, sin violencia: "Viendo lo cual, el cura pidió al escribano le diese por testimonio como había pasado desta presente vida y muerto naturalmente. Este fin tuvo el ingenioso hidalgo de la Mancha... Déjanse de poner aquí los llantos de Sancho, sobrina y ama de don Quijote, y los nuevos epitafios de su sepultura"4.

${ }^{4}$ Ibídem; “Dejemos reposar en la sepultura los ya podridos huesos de don Quijote, y no le quiera llevar, contra todos los fueros de la muerte, a Castilla la Vieja, haciéndole salir de la fuesa donde realmente yace tendido de largo a largo".

"Yace aquí el Hidalgo fuerte

que a tanto extremo llegó

de valiente, que se advierte

que la muerte no triunfó

de su vida con su muerte" (Sansón Carrasco). 
Todo un preciosista relato barroco de demostración de un 'buen tránsito', ejemplar y con aspiraciones celestiales: militante, acompañado, testado, rezado y llorado. Un documento piadoso muy popular, pero certificado ante notario, que buscaba la salvación eterna personal sin olvidarse de solventar los 'asuntos terrenales’ y más prosaicos del reparto patrimonial.

Junto al precedente y clarísimo, otros pasajes quijotescos también ofrecen bastantes claves para comprender la importancia de la muerte durante el Barroco y las principales actitudes populares, religiosas y funerarias, que habitualmente la acompañaban.

Así, en una de sus rocambolescas andanzas se toparon con gran multitud de lumbres, que a Sancho parecieron fantasmas y al ingenioso héroe peligrosa aventura ${ }^{5}$. Lo que finalmente descubrieron fue a numerosos 'descamisados' (en la oscuridad, los soldados -que en realidad eran clérigos- colocaban las camisas blancas sobre las corazas para diferenciarse del enemigo), a los cuales, rodeando unas andas cubiertas con paños negros, seguían otros caballeros enlutados hasta los pies de las mulas (en las ceremonias funerarias se usaban largos lutos talares por los fallecidos de calidad, incluyendo a sus cabalgaduras) y envueltos todos en unos faldamentos y lobas (sotanas holgadas propias de los escolares universitarios) que apenas les permitían moverse. Aquellos doce sacerdotes les comunicaron que acompañaban "un cuerpo muerto que iba en aquella litera, que murió en Baeza, donde fue depositado, y ahora llevamos sus huesos a su sepultura, que está en Segovia, de donde era natural”. Como había fenecido de unas fiebres y calenturas pestilentes que le dieron, don Quijote no podía intervenir, puesto que, "si otro alguno le matara, presto hubiese vengado su muerte; pero habiéndole muerto quien le mató, no hay sino callar y encoger los hombros”. La confusión quijotesca provenía de una situación que nos interesa ahora destacar: "el daño estuvo en venir como veníades, de noche, vestidos con aquellas sobrepellices, con hachas encendidas, rezando, cubiertos de luto, que propiamente semejábades cosa mala y del otro mundo; y, así, yo no pude dejar de cumplir con mi obligación acometiéndoos, y os acometiera aunque verdaderamente supiera que érades los mesmos satanases del infierno, que por tales os juzgué y tuve siempre...”. La respuesta también debe hacernos reflexionar: "advierta vuesa merced que queda descomulgado por haber puesto las manos violentamente en algo sagrado [vengándose así de la paliza recibida uno de los ordenados, tras recordar ese decreto del Concilio de Trento]"; lo mismo que la hidalga réplica final: "no entiendo ese latín, cuanto más que yo no pensé que ofendía a cosa de Iglesia, a

${ }^{5}$ Cervantes. Don Quijote; ‘Aventura de los encamisados y enlutados’, I, XX. 
quien respeto y adoro como católico y fiel cristiano que soy, sino a fantasmas del más allá”.

En resumen: Lo humano no es eterno. Acabamiento cuando menos se piensa. Visitado por sus amigos, el cura y el notario. El médico pide que se atienda la salud de su alma. Quiere confesarse y hacer testamento. "En tales trances no se burle el hombre con su alma". "El heredar templa las penas". Traslados de fallecidos (Felipe el Hermoso o san Juan de la Cruz). El poder del negro luto. Dios da la muerte. Presencia del demonio en el mundo. Excomunión y 'cosas de Iglesia'... Eran pensamientos recurrentes en la literatura y en la vida del Siglo de Oro español.

Por eso, varios congresos recientes han incidido en la importancia del Quijote desde nuevas perspectivas sociales, poniendo el acento en la 'plástica de su fragilidad corpórea' ${ }^{6}$.

Ciertas recreaciones pictóricas realizadas durante el siglo XIX sobre nuestro personaje caballeresco resaltan sus rasgos de 'locura' y 'enfermedad física'. Relacionando literatura e imagen, muestran la mentalidad decimonónica más que la propia realidad de la España del XVII. Aún así, añaden nuevos significados sobre la 'visión del ser quijotesco'. Aquel espíritu sublime, solitario, patético, vital e idealizado aparece en no pocas ocasiones en un cuerpo frágil, y hasta dramático y violento, como trastornado, malherido o enfermo de muerte. Su mirada reflejaba delirio, lo mismo que su figura consumida, su aislamiento o sus gestos convulsos ("visualizando lo imaginario, eran expresión de su genio", fruto del sueño, las lecturas y su imaginación desbordada -se pone en boca de Felipe IV la frase: "o lee el Quijote o loco está”-).

${ }^{6}$ Conferencia (Valladolid, 18 abril de 2005) de Carlos Reyero: "Loco, enfermo, herido. El cuerpo frágil de don Quijote como metáfora plástica en el siglo XIX”. Véase de este mismo historiador del Arte La belleza imperfecta: discapacitados en la vigilia del arte moderno (Madrid, 2005); y el Catálogo (Madrid, 2003) de las Exposiciones paralelas organizadas en el Museo del Prado: Imágenes del Quijote. Modelos de representación en las ediciones de los siglos XVII a XIX e Imágenes del Quijote. El proceso creativo de la imagen impresa, octubre 2003 - enero 2004.

Y en abril de 2005 se ha celebrado en la Universidad de Barcelona los Encuentros con la Historia Moderna dedicados a 'El Tiempo del Quijote’. Allí participaron: Ricardo García Cárcel, "El mundo del Quijote”, Alfredo Alvar Ezquerra, “Cervantes, historiador”, Jerónimo López-Salazar, "Hidalgos de carne y hueso" y Ofelia Rey, "La locura de los libros”. Remitimos a sus interesantes conclusiones sobre el encuadramiento temático del protagonista.

Y en septiembre de 2005, en Valladolid, tuvo lugar el Curso de Estío: 'Entre la Vida y la Muerte': Mentalidades en la Castilla Barroca Cervantina, coordinado por Máximo García Fernández. 
Además, nos interesa centrar el tema en el 'victimismo burlesco' del ingenioso hidalgo, patente en las obras de Jadraque, García Ramos, Fortuny, Moreno Carbonero, Vázquez Úbeda o Gustav Doré. Maestros que lo representan maltrecho, burlado, ridículamente caído en tierra y moviendo a la risa de quienes le contemplan (salvo por parte del fiel Sancho Panza). Sus heridas y enfermedades causaban risión, todo lo contrario que las de los monarcas, quienes suscitaban compasión y oraciones intercesoras. Su propia muerte en la cama, claro que fue llorada por sus amigos y familiares, pero debido básicamente a que había recobrado la cordura.

Y, desde otra perspectiva, al emparejar a Cervantes con don Quijote, identificando su imagen, su dramatización y su espíritu visionario, se produjo una permeabilidad y un asemejarse en los retratos del autor y del universal caballero andante. De la Peña o Nanteil representaron al protagonista sólo en la cárcel, desventurado, herido y héroe nacional o mostrando una triste figura para idealizar a un don Miguel quijotesco. Así, sus muertes (en los cuadros de Manzano, Eduardo Cano, Oliva o Antonio Muñoz Degrain), dado que la del novelista es prácticamente desconocida, tendieron a hermanarse y recrearse iguales: se asemejaban los lechos funerarios y también eran similares, contra toda lógica, los libros tirados por el suelo, sus desgracias físicas y hasta los personajes secundarios que les debieron rodear.

También la música ha reflejado sonoramente aquella instantánea final quijotesca. Así lo demuestran, por ejemplo, los Tres Epitafios compuestos por Rodolfo Halffter: "para la sepultura de Don Quijote", "para la sepultura de Dulcinea” y "para la sepultura de Sancho Panza”.

Poco sabemos del final de Cervantes ${ }^{7}$. Enfermo de hidropesía (ante la que no debió actuar según el sano dictamen de aquel joven estudiante: "vuesa merced ponga tasa al beber, no olvidándose de comer, que con esto sanará sin otra medicina alguna”), falleció un sábado 22 de abril de 1616. Apenas tres días después de sus últimos escritos al dictado para su póstumo Persiles dedicados a su buen amigo el conde de Lemos; aunque uno antes de su propia predicción fúnebre: "mi vida se va acabando al paso de las efemérides de mis pulsos, que a más tardar acabarán su carrera este domingo, acabaré yo la de mi vida”. A la que se une otro de sus pensamientos extremos: "puesto ya el pie en el estribo, / con las ansias de la muerte, / gran señor, ésta os escribo”, seguido de su íntima declaración postrera:

\footnotetext{
${ }^{7}$ Cenvantes. Prólogo y dedicatoria al conde de Lemos, Los trabajos de Persiles y Segismunda (Madrid, 1914).

Véase también: DeLFín, J. (2005). Cervantes en Valladolid. Valladolid, pp. 97-100.
} 
"ayer me dieron la extremaunción; el tiempo es breve, las ansias crecen, las esperanzas menguan; y, con todo esto, llevo la vida sobre el deseo que tengo de vivir y quisiera yo ponerle coto:... que podría ser fuese tanto el contento de ver a vuesa excelencia bueno que me volviese a dar la vida. Pero si está decretado que la aya de perder, cúmplase la voluntad de los cielos... que quiso pasar aún más allá de la muerte mostrando su intención... que ya no sería ventura, sino milagro, que me diese el cielo vida”. Once años antes estaba vivo en Valladolid junto a su hermana Magdalena, quien al ayudar a bien morir "por obligación de toda buena cristiana" al galanteador don Gaspar de Ezpeleta -tras las cuchilladas recibidas de un marido celoso; y gracias a las ‘averiguaciones judiciales' pertinentes-, nos permiten fechar la presencia cervantina en la corte vallisoletana. Si hizo testamento, aún no se ha encontrado. Fue enterrado en el convento de los Trinitarios de Madrid con sayal franciscano y el rostro descubierto -según regla de su venerable orden tercera.

"Adiós gracias, adiós donaires; adiós, regocijados amigos: que yo me voy muriendo, y deseando verso presto contentos en la otra vida”. Es la salutación y despedida terminal de un católico que sentía abandonar esta vida pero que, en la seguridad de su pronta partida, esperaba en la resurrección definitiva y gozosa junto a sus íntimos allegados. Ejemplar hasta en el morir.

En fin, el Quijote es una ‘metáfora de la vida como teatro' (y del ‘sueño de la vida') al presentar las 'culturas y cosmovisiones del Barroco' cuando las sensibilidades que dotan esa imagen de sentido eran tanto de raigambre culta como popular, así como también de índole íntima y visual, anímica y escénica. Por eso, cuando caballero y escudero conversaban sobre la representación del Auto de Las Cortes de la Muerte (II, XII) decían: "en llegando al fin, que es cuando se acaba la vida, a todos [poderosos] les quita la muerte las ropas que los diferencia, y quedan iguales en la sepultura”. Modelo que confluye claramente con el calderoniano: las 'situaciones dramáticas' concluyen con el despertar quijotesco frente a su propia muerte, lo que significa la aceptación final de su papel espectacular y de toda la lección barroca del desengaño.

\section{LA AGONÍA POPULAR Y LITERARIA: CLAVES DE LA RELIGIOSIDAD COLECTIVA BARROCA}

Aquellos lutos sólo se relacionaban en parte con los famosos 'duelos y quebrantos’, típicos de los sábados, de don Quijote ${ }^{8}$. Plato que no rompía la abstinencia sabatina de comer carne; y que consistía en los habituales 'huevos con

${ }^{8}$ Cervantes. Don Quijote, I, I. 
tocino' de la dieta castellana o en las populares 'lentejas', a ingerir los días de ayuno, en un potaje aderezado con ajo y cebolla.

* El hambre del pícaro Lazarillo también relacionaba ciertos aspectos funerarios con los alimenticios ${ }^{9}$. Así, en alguno de sus discursos se relataba que en las cofradías, sus rezos mortuorios siempre se acompañaban de comida, bebiendo muchísimo más. En sus exequias, no podían faltar las ofrendas de pan y vino que llevaban los fieles a la iglesia. Y también los refrigerios eran costumbre arraigada en las honras fúnebres y en los acompañamientos de difuntos, momento en el que la familia convidaba a eclesiásticos y familiares. "Cuando moría algún feligrés, toda la hacienda le comíamos con mucho placer en su entierro, pues teníamos aquellos días muy grandes papilorrios, obladas y pitanzas de muertos”. De igual manera que recordaba, ya desde su hartazgo final, como su anterior amo, el buldero, "siempre llevaba a los clérigos del lugar algunas cosillas para tenerlos propicios y poder vender sus bulas”.

Por eso también, cuando enfermó un compañero de El Buscón, el dómine Cabra “detuvo el llamar al médico hasta que ya pedía confesión”. Tomándole el pulso, éste sentenció que: "el hambre le había ganado por la mano en matar a aquel hombre. Diéronle el Santísimo Sacramento"; llevaba un día sin hablar y dijo: "Señor mío Jesucristo, necesario ha sido veros entrar en esta casa para persuadirme que no es el Infierno. Imprimiéronseme esas razones en el corazón. Enterrámosle pobremente por ser forastero. Divulgose en el pueblo este caso atroz"10.

Desde otra perspectiva igual de vital, don Pablos también constataba el protagonismo de los aspectos funerarios y trascendentes, espiritualizados, al narrar sus cuitas. Destacamos las más significativas. "Señor ¿sabéis de cierto si estamos vivos?”, decía ya acostado en la cama, después de no comer ni cenar nada en su mísero pupilaje, "imagino que en la pendencia de las berceras nos mataron, y somos ánimas que estamos en el Purgatorio; y así, es por demás decir que nos perdonen allá, si alguno no nos reza en alguna cuenta de perdones y nos saca de penas con misas en algún altar privilegiado”. Además, el muy rufián, vestido de 'santero' con un sayal pardo, cruz grande, barba postiza y rosario "andaba de noche diciendo: 'acordaos de la muerte, y haced bien hermanos por las ánimas' al son de su campanilla; cogía [así] muchas limosnas”"11.

${ }^{9}$ ANÓNImo (1554). La vida del Lazarillo de Tormes. Durante el siglo XVII, tratando de conservar la pureza de la ortodoxia, llegó a considerarse anticlerical, incluyéndose en los Índices de libros prohibidos por la Inquisición.

${ }^{10}$ Quevedo, F. de (1626). El Buscón (don Pablos). Zaragoza, 1626, p. 47.

${ }^{11}$ Quevedo. El Buscón, pp. 42 y 193. 
"Vuestro padre murió con el mayor valor. Subió en el asno sin poner pie en el estribo. Veníale el sayo [de ajusticiado] que parecía haberse hecho para él. Iba con gran desenfado mirando a las ventanas y haciendo cortesías a los que dejaban sus oficios por mirarle. Hízose dos veces los bigotes. Mandaba descansar a los confesores, alabándoles mucho lo que decían. Puso un pie en la escalera, no subió a gatas ni despacio, que no todos tenían sus hígados. No sabré encarecer cuán bien pareció a todos. Sentose arriba, tiró de las arrugas de la ropa, tomó la soga y púsola en la nuez, y viendo que el teatino le quería predicar, dijo 'padre, yo lo doy por predicado, vaya un poco de Credo y acabemos presto, que no querría parecer prolijo'. [Con la caperuza de lado y limpias las barbas] cayó sin encoger las piernas ni hacer gesto. Quedó con una gravedad que no había más que pedir. Hícele cuartos, y dile por sepultura los caminos. Dios sabe lo que a mi pesa verle en ellos, haciendo mesa franca a los grajos”.

\section{$\mathrm{O}$}

"Vuestra madre está presa en la Inquisición, porque desenterraba los muertos sin ser murmuradora [bruja que quitaba las muelas a los ahorcados para conjuros]. Hallaron en su casa más piernas, brazos y cabezas que en una capilla de milagros. Representará en Auto de Fe el día de la Trinidad, con cuatrocientos de muerte; pésame, que nos deshonra a todos, pues están muy mal estos parentescos". Actos de adoctrinamiento público a los que concurrían multitudes para ver las insignias y trajes de los penitentes, descubierta su cabeza, con una vela en la mano o con sus sambenitos y corazas de relajados. "Todo con tan buen orden que era cosa muy de ver"12.

"Dios es mi padre, que no come un cuerpo más presto el montón de la Antigua de Valladolid, que lo deshace en veinticuatro horas, que yo despache el ordinario". La tierra de su cementerio, junto al cercano de Esgueva, tenía fama de haber sido traída por los cruzados del 'Campo Damasceno', y que, por ser sagrada, consumía muy rápidamente los cadáveres $^{13}$.

Almas purgantes, bulas de difuntos, horcas y hogueras aleccionadoras de 'malas muertes', campo santos, familiaridad con el más allá...: la 'caducidad de la vida' y la 'eterna preparación fúnebre’ como temas recurrentes. Y si la novela picaresca mostraba la crudeza sacralizada del óbito, entre lloros y melancólicos finales, el teatro del Siglo de Oro redundaría plásticamente en ese mismo alegato postmortem, omnipresente siempre, teñido de lutos y de reflexiones agónicas.

\footnotetext{
12 Quevedo. El Buscón, pp. 92 y 94.

${ }^{13}$ QueVEDO. El Buscón, p. 184.
} 
* De igual forma que una breve pieza postrimera cervantina nos brinda la posibilidad de comparar sus argumentos sobre la presencia cotidiana de la muerte en la Castilla Barroca con la que también reflejaron otros muchos escritos tanáticos de la época ${ }^{14}$. Dado el interés popular por la trascendencia, todas esas manifestaciones ideológicas eran de sobra conocidas, ofreciendo un buen escaparate existencial para comprender mejor aquellas mentalidades.

"Ven, muerte, tan escondida, que no te sienta venir, porque el placer del morir no me torne a dar la vida" ${ }^{, 5}$.

Las expresiones literarias y pictóricas del universo barroco estaban presididas por la contradicción. Culturalmente, el desengaño fue un tema muy reiterado (la crisis general del momento enfatizó esa tendencia). Desarmonía, oposición de contrarios y dualismo, mudanza, desconcierto, existencialismo, fugacidad, caducidad, perpetua agonía, pesimismo vital macabro, epitafios... eran ideas recurrentes. "Lo angélico y lo demoníaco, materia y espíritu, razón e instinto, luz y sombras de inseguridad” eran las dualidades de don Quijote y Sancho Panza ${ }^{16}$.

"Ayer se fue; mañana no ha llegado;

hoy se está yendo sin parar un punto;

soy un fue y un será y un es cansado.

En el hoy y mañana y ayer, junto

pañales y mortaja, $y$ he quedado

presentes sucesiones de difunto" ${ }^{\text {17. }}$.

14 Véanse: Rodríguez-SAn Pedro, L. E. (1988). Lo Barroco: la cultura de un conflicto. Salamanca, pp. 40-53; ROSALES, L. (1966). El sentimiento del desengaño en la poesía barroca. Madrid; y SÁNCHEZ LORA, J. L. (1985). Mujeres, conventos y formas de religiosidad barroca. Sevilla.

${ }^{15}$ Cervantes. Don Quijote, 'La dueña dolorida', II, XXXVIII.

${ }^{16}$ RodríGUez-SAN PEDRO, L. E. op. cit., p. 45.

17 "Represéntase la brevedad de lo que se vive”; QUEVEDo (1998). Sueños: sueños y discursos de verdades descubridoras de abusos, vicios y engaños, en todos los oficios y estados del mundo. Madrid.

QUEVEDO (1634). La cuna y la sepultura: para el conocimiento propio y desengaño de las cosas ajenas (Doctrina Moral. Doctrina para morir). Proemio. Defensas del Tratado: "Que no desconfíe por sus pecados de la misericordia de Dios, fiando en ella, en su sangre y en la intercesión de los santos. Y, la segunda, que no se confíe en algunas buenas obras que a su parecer ha hecho, porque no le condene la presunción propia asegurada en sí”.

"Es pues la vida un dolor en que se empieza / el de la muerte, que dura mientras dura ella". 
Se trataba de una agria crítica quevedesca, y en general de toda la literatura del Siglo de Oro, al hombre, a la vida y a sus desengaños, ya desde la cuna. El 'carpe diem' transmutado en 'memento mori'. Así, el castellano, frágil y expectante, vivía en un mundo incierto y hecho en exclusiva de apariencias. Tiempos de inseguridad, dudas, 'velas' e insatisfacciones; crispados; “con sabor a postrimería”. Todo incluido dentro del más genérico paradigma social de la época: de Lope de Vega ${ }^{18}$ ("la honra es patrimonio del alma, / y el alma sólo es de Dios”), de muchas de las obras de Shakespeare o de la célebre composición calderoniana La vida es sueño ${ }^{19}$ :

“Cuán breve sea esta vida, cuán incierta, cuán frágil, cuán inconstante, cuán engañosa y, finalmente, cuán miserable; y después el fin, a que vienen a parar, que es la muerte" 20 .

"[Al hombre, extranjero] recíbele aquel primer embustero que es el Mundo, ofrécele mucho y nada cumple, dale lo que a otros quita para volvérselo a tomar con tal presteza que lo que con una mano le presenta con la otra se lo ausenta, y todo para en nada. Aquel otro que le convida a holgarse es el Gusto, tan falso en sus deleites cuan cierto en sus pesares; su comida es sin sustancia y su bebida venenos. Da con todo en tierra. Llega la Salud que cuanto más le asegura más le miente. Aquellos que le dan priesa son los males; las Penas le dan y gritan los Dolores: vil canalla toda de la Fortuna. Finalmente, aquel viejo peor que todos, de malicia envejecida, es el Tiempo, que le da el traspié y le arroja en la sepultura, donde le deja muerto, sólo, desnudo y olvidado".

"Todo cuanto hay se burla del miserable hombre; el mundo le engaña, la vida le miente, la fortuna se burla, la salud le falta, la edad se pasa, el mal le da priesa, el bien se le ausenta, los años huyen, los contentos no llegan, el tiempo vuela, la vida se acaba, la muerte le coge, la sepultura le traga, la

18 Por ejemplo: Vega, L. de (1895). Comedias de vidas de santos. Madrid; La creación del mundo y primera culpa del hombre. Zaragoza, 1972; El niño inocente de la guardia. Londres, 1985; Porfiar hasta morir. Pamplona, 2004; o Triunfo de la fee en los reynos de Japón. Londres, 1965.

19 De Pedro Calderón de la Barca (1600-1681). Sus primeras producciones literarias se situaron, precisamente, en el certamen poético celebrado en Madrid con motivo de la beatificación de san Isidro en 1620. Véanse, del mismo tema: CALDERóN, P. (1970). Comedias Religiosas. 1 La devoción de la Cruz; y 2 El mágico prodigioso. Madrid, 1970; La vida es sueño. Madrid, 1992; y El gran teatro del mundo; El gran mercado del mundo. Madrid, 1979.

${ }^{20}$ GranADA, L. de. Memorial de la vida Christiana: se enseña todo lo que un christiano debe hacer desde el principio de su conversión hasta el fin de la perfección. Madrid, 1769; o su Guía de pecadores. Madrid, 1966. 
tierra le cubre, el olvido le aniquila y el que ayer fue hombre hoy es polvo y mañana nada",21.

“Tú eres, tiempo, el que te quedas / y yo soy el que me voy”.

'Carpe Diem': / “Goza cuello, cabello, labio y frente

antes que lo que fue en tu edad dorada,

oro, lirio, clavel, cristal luciente,

no sólo en plata viola trocada

se vuelva, más tú y ello juntamente

en tierra, en humo, en polvo, en sombra, en nada"22.

* En la España de la primera mitad del siglo XVII también Zurbarán, Ribera, Herrera el Mozo o Pereda, a través de sus sueños, engaños, vanitas y martirios, reflejaron plásticamente que la muerte 'eternamente punza, deprisa vuela y mata', al ser un 'denso enjambre de negras alas, hilo sutil de arena numerosa' hecho 'de polvo y tiempo y sueño y agonías'23. Así, desde su conciencia de contradicción pictórica, la realidad barroca fue una 'agonía conflictiva'; y por eso las repercusiones de ese viraje en la religiosidad del momento marcarían un repliegue hacia las seguridades de la ascética frente a la mística y el triunfo de lo popular y de las obras externas (afianzando la omnipresencia ignaciana contra la vía jansenista), movilizando los impulsos vitales de la piedad militante tradicional, plena de un activismo tan rígido como disciplinado.

Antonio de Pereda, en su soberbia Vanitas, desplegaba ante el espectador los objetos del placer y de la fama en el mundo: cadenas de oro, naipes, piezas de armadura, libros, perlas, monedas, perfumes, retratos... (16??). Pese a su brillantez, sólo eran trofeos vanos que perdían la batalla al enfrentarse a la severidad de las calaveras y de la propia muerte. El paso del tiempo, representado por los relojes y una vela apagada, les reducía a la nada ('nihil omne' grabado en la mesa). En el centro de la composición se visualizaba el pasado, los emperadores Augusto y

${ }^{21}$ Gracián, B. (1971). El Criticón. Madrid, I, VII; "No hay cosa más deseada ni más frágil que tú eres [vida], y el que una vez te pierde, tarde te recupera”, I, I; “Todos le sacuden y le arrojan, hasta que reventado viene a parar entre la azada y la pala, en el lodo y en la hediondez de un sepulcro", I, VIII.

${ }^{22}$ GÓNGORA, L. de (1981). Sonetos completos. Madrid; y Antología. Madrid, 1976.

23 "El oficio de la fe es purificar el alma de estos errores, y despertarla del profundo sueño y engaño en que está por la ceguedad del pecado"; NiEREMBERG, J. E. (1651). Del aprecio y estima de la gracia divina (Madrid, 1957, p. 416).

En la pintura, los temas de 'vanitas', 'la vida es sueño', los 'simulacros y emblemas de espejos', las 'luces mágicas', etc. eran recurrentes: “arrojando al cielo [el otro azul] su tormento, / más allá del azar y de la muerte”. 
Carlos V, salvados del pasado histórico pero presentando como fugaces las apariencias y locuras terrenales, y siempre en manos del omnipresente ángel celestial. Este género pictórico sólo se explica vinculado a la 'literatura de postrimerías'. Ante la violenta y angustiosa pedagogía de la parca, ambas manifestaciones artísticas gozaban del carácter de advertencia universal:

"Llega a un osario, que está lleno de huesos de difuntos, distingue entre ellos el rico del pobre, el sabio del necio. Todos son huesos, todos calaveras, todos guardan una igual figura. La señora acompaña a las calaveras de los mendigos. Las cabezas que vestían penachos de plumas en las fiestas de la corte acompañan a las calaveras que traían caperuzas en los campos" ${ }^{24}$.

De esos lienzos surgía una figuración del desengaño. El tiempo, el 'memento mori', era el protagonista. El hombre no debía olvidar que moriría, pero tampoco que en ese instante del ciclo vital cesaba también toda apariencia y vanidad. Se trataba de una renovada 'danza macabra', aunque la muerte barroca restableciese la proporción, el equilibrio, y recuperara el orden; pero sin igualar ni siquiera entonces jerárquicamente a todos, claro está, en su refugio eterno final celestial o de condena, para justos o pecadores, tras la culminación del juicio final.

* Aunque con mayores fundamentos teológicos y morales, lo mismo se apreciaba en la literatura religiosa. La parca estaba instalada en el centro de la vida, como recordaban esqueletos y hoces, mientras su memoria se reforzaba mediante la figuración artística. La "buena muerte" fue tema ejemplar, provocando tal familiaridad que su renombre era todo un espectáculo eficaz de meditación, hasta convertirse en un acto de trascendencia y edificación colectivas: apocalíptica, deseada, pedagógica, amedrentadora y niveladora ${ }^{25}$. Así también, las visiones del cielo y del infierno aparecían plásticamente reconocibles. Las detalladas descripciones de sus 'moradas' excitaban el anhelo de la consecución de lo deseado y el alejamiento de lo temido ${ }^{26}$.

¿Cómo se figuraban el cielo ${ }^{27}$. Entre otras recreaciones hiperefectivas, desde una de sus puertas, fray Juan de la Miseria describía 'la patria celestial' como una transposición realista del mundo, aunque ganando en excelencia, armonía y

${ }^{24}$ MAÑARA, M. de (1617). Discurso de la verdad. Sevilla, p. 24.

25 García Fernández, M. (1995). Herencia y patrimonio familiar en la Castilla del Antiguo Régimen (1650-1834). Efectos socio-económicos de la muerte y la partición de bienes. Valladolid; y (1996). Los castellanos y la muerte. Religiosidad y comportamientos colectivos en el Antiguo Régimen. Valladolid.

${ }^{26}$ Véase: MARTínEz ARAnCón, A. (1987). Geografía de la eternidad. Madrid.

${ }^{27}$ Mc DanNell, C. y LANG, B. (1990). Historia del Cielo. Madrid. 
etiqueta a las vanas apariencias de la 'locura del desierto terrenal': entre coros angélicos, interminables procesiones de vírgenes y de santos hacían calle para contemplar mejor a la divinidad ${ }^{28}$. La eternidad mantenía un perpetuo orden, y como tiempo y cambio no eran posibles, se producía entonces la sublimación religiosa.

Y en la agonía, la batalla era cruenta; encarnizada: "condenado al infierno por mis muchos pecados, en el tribunal de Dios no encontraré misericordia”. Los confesores debían responder a todas las insinuaciones demoníacas. Ante esas ideas, las Prácticas para ayudar a bien morir fueron lectura capital de moralistas y predicadores. Todos debían tener presente la "memoria de la muerte" y prepararse para un buen tránsito, convirtiendo entonces al clero en protagonista absoluto ${ }^{29}$.

\section{OTRA CARA DE LA MUERTE: EL IMPACTO PÚBLICO DE LAS HONRAS DURANTE EL SIGLO XVII}

Así, el obispo de Badajoz, sin exageración notable, se lamentaba en 1624 de que "hay quien diga que se ha hecho ya la religión modo de vivir, y que algunos se ponen a fraile como a oficio”30. Y como ya desde la recepción del bautismo -o el 'agua de socorro'-, la 'matrícula de confesión' o la 'cédula de cumplimiento pascual', se entraba bajo la tutela vital eclesiástica (por ejemplo, no guardar las fiestas era motivo de escándalo público y de multas, y los médicos tenían la obligación de avisar a los enfermos graves para que confesasen y dejar de asistirlos si no lo hacían al tercer día) hasta justo sus funerales, el refugio clerical barroco era omnipresente. Además, el despliegue misional de recristianización contrarreformista del momento tuvo como objetivo el enfervorizar al pueblo,

${ }^{28}$ CARo BAROJA, J. (1999). Las formas complejas de la vida religiosa. Religión, sociedad y carácter en la España de los siglos XVI y XVII. Barcelona, 2 vols. Anota diversos tratados que describen físicamente el cielo, pp. 142-144.

29 Bosch De Centellas, B. (1696). Prácticas de visitar a los enfermos y ayudar a bien morir; "Contiene piadosos y saludables avisos contra las engañosas astucias del enemigo común; obra muy útil para los confesores...”.

Adquiría plena notoriedad en el espectáculo callejero del viático, en la veneración procesional del 'Santísimo en público a los enfermos' y ante los benéficos y reconfortantes efectos de la reverenciada extremaunción.

De ahí también las múltiples reediciones, desde que apareció en el siglo XVII, de la obra del padre José Boneta y Laplana: Gritos del purgatorio y medios para acallarlos, Zaragoza, 1689.

30 Deleito y Piñuela, J. (1952). La vida religiosa española bajo el Quarto Felipe. Santos y pecadores. Madrid, p. 79. También: AlemÁN, M. (1604). Guzmán de Alfarache (Barcelona, 1983), II, 3; "Tomé resolución de hacerme de la Iglesia, no más porque con ello quedaba remediado, la comida segura y libre de mis acreedores...”. 
induciéndole a un cambio de costumbres y a un mejor cumplimiento de sus obligaciones pías. Por eso, y para impresionar más al auditorio, las órdenes regulares utilizaban en sus prédicas todo tipo de recursos teatrales (exhibían calaveras o tétricas representaciones del infierno y de las almas condenadas). Artificiosidad y efectismo escénico, mayor expresión visual del sentimiento piadoso, desmesura y ostentación se convirtieron en las claves de la religiosidad castellana frente, o en un amplio viraje respecto, a la explosión mística precedente. "Las ceremonias del culto se complican y enriquecen, los actos de piedad colectiva se multiplican, las grandes solemnidades originan espectaculares manifestaciones que pueden prolongarse durante días [como ocurrió con la triple canonización en 1622 de santa Teresa, san Ignacio de Loyola y san Francisco Javier]"31. El culto a los santos, a sus reliquias y a la Virgen María (del Pilar, de Montserrat, de Guadalupe o bajo su advocación Inmaculada) también se reforzaron tras el concilio de Trento, lo mismo que los 'arrebatos místicos' de muchas monjas en sus numerosos conventos se sobredimensionaron: "cunde tanto esto de las llagas -escribía en 1634 un jesuita- que no se tiene ya por sierva de Dios la que no tiene las cinco"32. Asimismo "se desató una lucha sin cuartel contra cualquier libro, idea o práctica religiosa que se aparte lo más mínimo de la doctrina oficial de la Iglesia; abriéndose ahora muchos procesos contra cristianos viejos, convertido el Santo Tribunal en atento y feroz vigilante de las costumbres y en instrumento de disciplina y reforma popular". Y ante la obsesión por las brujas y el demonio, tanto se difundió la abundantísima literatura demonológica, analizando los poderes y facultades del maligno, y describiéndose con todo lujo de detalles la corte infernal (Satanás, Barrabás, Lucifer, Belcebú, Leviatán, Astarot o el Diablo Cojuelo trataban de perder a los humanos con su concupiscencia), que cualquiera de esos espíritus diabólicos acechaban con frecuencia a los mortales (a juzgar por la enorme cantidad de apariciones -en muchos cenobios femeninos- o por las menos habituales 'posesiones', frente a las que sólo cabía el recurso especializado a los exorcistas). En resumen: todo un complejo y férreo control de las conductas para conservar la pureza de la ortodoxia, en el que la fuerza de la Inquisición también tuvo mucho que ver con el asentamiento de aquella piedad formalista y hueca. En suma: "se insistía en los aspectos externos de la devoción, en la representación continua de la muerte y el infierno como motivos para obrar, en la inanidad de lo temporal como excusa para no intentar su reforma. Se exageró el tabú sexual hasta convertirlo en el centro del problema moral de la salvación eterna, y en su nombre

31 AlcalÁ-Zamora, J. (19??). op. cit., Madrid; 'La Iglesia y la religiosidad’, pp. $255-278$ (p. 271).

32 DeLEITO, J. op. cit., pp. 204-235. 
se combatieron bailes, comedias e inocentes diversiones. La religiosidad caballeresca predominante durante el Renacimiento, cristiana en el fondo pero libre en las formas y de fuerte acento secular, fue sustituyéndose por otra, en apariencia más religiosa, pero más estrecha”33.

Oraciones, limosnas, disciplinas, plegarias, traslados de reliquias, novenarios, ofrendas de cera, misas y procesiones públicas constituyeron eficaces instrumentos y actos impetratorios utilizados en la época para combatir las calamidades y paliar los efectos de la muerte. Las epidemias, pedriscos, malas cosechas, la falta o abundancia de agua, el azote de la langosta o los desastres de la guerra, con frecuencia, obligaron a organizar estas manifestaciones colectivas clamando a la divinidad por el cese de la adversidad. La enfermedad de las personalidades de renombre también obligó a recurrir a esas prácticas, multiplicadas cuando el rey agonizaba; entonces se movilizaban aún más aquellos resortes y liturgias sacros ${ }^{34}$.

Por eso, durante el Barroco, las advocaciones del santoral y la presencia de los relicarios fue determinante en la conformación de la mentalidad colectiva. Ya lo escribió Cervantes (Quijote, II, VIII): “los cuerpos de los santos o sus reliquias llevan los reyes sobre sus hombros, besan los pedazos de sus huesos, y adornan y enriquecen sus más preciados oratorios y altares”. Así, la Iglesia acentuaría su valor taumatúrgico y contrarreformista, aprovechando el profundo poso popular tradicional en el que su culto estaba tan asentado, pues "viven con Jesucristo, quien hace por ellas muchos beneficios al hombre”. De ahí que se les rindieran tantos honores procesionales ${ }^{35}$. En definitiva, la 'religiosidad profesada' pugnaba con la

33 AlCalÁ-Zamora, J. op. cit., 'La Iglesia y la religiosidad', pp. 255-278 (pp. 275 y 278).

${ }^{34}$ VARELA, J. (1990). La muerte del rey. El ceremonial funerario de la monarquía española: 1500-1885. Madrid; SÁNCHEZ LORA, J. L. (1994). "Religiosidad popular, un concepto equívoco”. En Serrano, E. (ed.). Muerte, religiosidad y cultura popular. Siglos XIII-XVIII. Zaragoza, pp. 65-79; y WOODWARD, J. (1997). The theatre of death. The ritual management of royal funerals in Renaissance England: 1570-1625. Woodbridge.

CORTÉs, L. (1995). "Entre la religiosidad popular y la institucional. Las rogativas en la España Moderna”. Hispania, $\mathrm{n}^{0}$ 191, pp. 1027-1042; "La ceremonia de rogativa no siempre era la misma. Podía complicarse o simplificarse según la intensidad y necesidad requerida con un sinnúmero de preces, letanías, músicas, campanas...”.

De esta forma, las celebraciones litúrgicas multiplicaron su duración, fomentando el rezo vocal y dirigido, y magnificadas a través de los ricos ropajes eclesiásticos, la música y la imagen al servicio de la difusión catequética del mensaje católico y la decoración de los templos -desbordándose hacia las calles-. Conscientes de la utilidad de tales rituales ceremoniales, defensivos y ofensivos, la jerarquía los empleó con asiduidad para diferenciarse de los planteamientos luteranos, a la vez que mostraban una Iglesia poderosa y favorecida por Dios frente a sus enemigos.

35 De igual manera que se significaba que además de ser queridas por Dios servían para combatir al maligno: "Estima Dios en mucho las reliquias de sus santos. Tiénelas y aprécialas en tanto que las 
'vivida'. Nada de oración mental, individualismo, erasmismo ni exaltación del contenido: maquinaria tridentina, ortodoxia e Inquisición, sí. Una 'religión de imágenes' frente a otra 'de textos'.

Así, forzosamente se acrecentó el abuso de imágenes, reliquias y culto a los santos. Y por eso se censuraba a España ser "un inmenso barrizal de ídolos... fama que tenía sorbido el seso a todos sus naturales”36. Los ritos mal entendidos eran reprobados y las críticas de la jerarquía católica a su excesiva y frecuente manipulación arreciaron ${ }^{37}$. Erasmo o Valdés ${ }^{38}$ tendieron a la sencillez y a no revestirlos de tanto artificio: no se rechazaba el ceremonial pero criticaban los excesos y oropeles que alejaban las mentes de los verdaderos mensajes. Sin

sienta en el Libro de Caja del ha de haber de sus tesoros. No hay cabello de ellos que no esté en él por su cuenta y razón, y la tiene tan grande de todos que ni uno sólo se le pierde; y si llegamos a tratar de sus huesos, pónelos en su guardajoyas... que con ser los Demonios furias infernales, las pierden en presencia de las reliquias santas y tiemblan como azogados”; fray PRIETO, M. (1639). Crónica y Historia de la real ciudad de Burgos... 2 tomos; Biblioteca Nacional (BN), f. 157.

36 "Las limosnas sólo servían para mantener a un grupo de frailes ociosos y holgazanes interesados en aumentar sus ganancias y en mantener el monopolio de la idolatría, transformándolas en beneficios con los que se ceban como puercos”; Melgosa, Ó. Los burgaleses ante la enfermedad y la muerte de sus Reyes: rogativas y honras fúnebres reales en la ciudad de Burgos en los siglos XVI y XVII (Tesis doctoral inédita, UBU, 2005, p. 148).

"Ninguna cosa santa ni profana podemos alcanzar sino por dineros. Al bautismo, dineros; al matrimonio, dineros; a las sacras órdenes, dineros; para confesar, dineros; para comulgar, dineros; no os darán la Extremaunción sino por dineros; no tañerán las campanas sino por dineros; no os enterrarán en la iglesia sino por dineros; no oiréis misa en tiempo de entredicho sino por dineros; de manera que parece estar el paraíso cerrado a los que no tienen dineros”; VALDÉs, A. de (1956). Diálogo de las cosas ocurridas en Roma. facsímil, Madrid, p. 66.

${ }^{37}$ Véase: BuRKE, P. (1991). La cultura popular en la Europa moderna. Madrid.

Proposiciones de los Alumbrados condenadas como heréticas por la Inquisición ya en 1525: "Era idolatría ataviar a la imagen de Nuestra Señora y sacarla en procesión por la calle... Hacer reverencia a la imagen de Nuestro Señor, que eran palos... No se había de pedir a Dios cosa en especial porque siempre tenía cuidado de todos”; CHRISTIAN, W. A. (1991). Religiosidad local en la España de Felipe II. Madrid, p. 196.

${ }^{38}$ VALDÉs, A. op. cit. "Hallaréis infinitas reliquias por el mundo, y se perdería muy poco el que no hubiese pues... allende su incertidad, es una vergüenza muy grande ver lo que en algunas partes dan a entender a la gente... qué cosas más ridículas e impías... serían para haceros morir de risa. El que quiera honrar a un santo debería trabajar de seguir sus virtudes, y ahora, en lugar de esto, corremos toros en su día, allende de otras liviandades”, pp. 14 y 130.

"Al mismo género de locura corresponde la costumbre de que cada comarca reclame para su uso un santo particular y de que a cada uno de ellos se lo venere con culto distinto y se le atribuya una virtud especial... Las ceremonias, aunque no deben desdeñarse, consideradas en si mismas son de poco provecho, e incluso pueden ser perniciosas, si no se penetra por medio de ellas en lo espiritual; o sea, en lo que los símbolos visibles representan”; RótTERDAM, E de (1999). Elogio de la locura. facsímil, Barcelona, pp. 54 y 103-104. 
embargo, sólo era un pensamiento minoritario e irreconciliable con la religiosidad profesada por la mayoría de la población, entre quienes arraigó la defensa del valor del ritual (afectado, hueco, retórico, ostentoso y vacío), la ceremonia magnífica, la pompa y una devoción colectiva y exteriorizada, que trascendía el ámbito del templo e inundaba la calle: barroca y ortodoxa.

Y más beneficio espiritual cuanto mayor fuese el número de personas pidiendo auxilio divino y se elevase la cantidad de los sacrificios ofrecidos (por eso se castigaban las ausencias o se atraían las comparecencias, incluso con multas pecuniarias). Así, no extraña que "el cabildo, las religiones y la clerecía, juntamente con la ciudad, y detrás muchas personas suplicando a $\mathrm{N}^{\circ}$ Señor con ardentísimo afecto y lágrimas" apareciesen en aquellas procesiones fúnebres o que al acudir a hacer rogativas "y traer la santa imagen de la Virgen Blanca a esta Iglesia, ocurriese un gran gentío a hacer oración”39, respetando siempre todos el orden riguroso correspondiente.

* En ese contexto, las recopilaciones sobre enfermedades y muertes santas, exequias (etiquetas y túmulos), honras, oraciones y sermones muestran la importancia de las postrimerías. Así, los fallecimientos eran expresión de religiosidad externa, de duelo festivo y de 'obligación' en los pésames y lutos. Los intereses de aquellas exequias se decantaban por el ceremonial ${ }^{40}$.

Las honras fúnebres coetáneas "al dejar sempiterna memoria de todas las efímeras celebraciones organizadas en honor de la monarquía”, junto a las dotes para casar doncellas y los legados testamentarios píos realizados por los príncipes, así como el reparto entre muchos conventos castellanos de las treinta mil misas encargadas personalmente por la salvación de sus almas durante el siglo XVI y más

39 Archivo Catedral de Burgos, Actas Capitulares, 1619; Archivo Municipal de Burgos, Actas Municipales, 1621.

${ }^{40}$ Procesiones, oraciones, imágenes y misas (“de sentimiento y demostración”) eran continuamente ordenadas por el Reino durante las enfermedades regias; véanse: Actas de Cortes castellanas modernas y VARELA, J. op. cit. 
en pleno Barroco, tras heredar esa práctica de la tradición carolina ${ }^{41}$, reflejan el protagonismo socioeconómico y político de aquellas muertes ${ }^{42}$.

Antes de fallecer, los reyes sufrían las molestias de sus males característicos; a los que se exponían con mayor asiduidad que sus pecheros debido a su diferente estilo de vida alimenticio ${ }^{43}$. Las reinas también padecían en extremo (y no sólo físicamente) sus numerosos alumbramientos ${ }^{44}$, compensados por la manifiesta alegría expresada mediante festejos solemnes cuando su vasta progenie crecía, y básicamente cuando se trataba de primogénitos y herederos al torno. Entonces, cuando la sucesión estaba garantizada y, por lo tanto, la enfermedad ya no podía ser considerada como un justo castigo divino a los pecados y desvíos generales, sí que cualquier luto, aunque ampliamente llorado, también podía tornarse en regocijo popular y en acción colectiva de gracias a la caritativa voluntad de lo Alto. Como los agentes urbanos tenían, con frecuencia, buena información de primera mano de las recaídas regias se sucedían entonces las oraciones, 'buenas obras', plegarias y rogativas para congraciarse y recuperar de nuevo el beneficio celestial y alcanzar su ansiado restablecimiento, tras corregirse los errores colectivos y superar los remordimientos reales (que tanto asolaron a Felipe III en su lecho de muerte) ${ }^{45}$.

Así, la propia monarquía planteaba la mejor forma de aprovechar, para la salud de sus almas, la publicidad de la administración del viático y la extremaunción, utilizando las agonías regias como modelo a seguir por toda su República en la

${ }^{41}$ Monreal, M. J. (1696). Imperiales exequias que en la muerte de la Serenísima Reyna de España Doña María Ana de Austria celebró la ciudad de Zaragoza. BN, Ms. 3/13947.

Véanse: GonzÁLEz DÁviLA, G. (1650). Teatro Eclesiástico de las Iglesias Metropolitanas de los reynos de las Dos Castillas. Madrid; Polanco Melero, C. (2001). Muerte y sociedad en Burgos en el siglo XVI. Burgos; y VVAA. (2000). Glorias efímeras. Las exequias florentinas por Felipe II y Margarita de Austria. Valladolid.

${ }^{42}$ Véanse: BouZA, F. (1998). Imagen y propaganda. Capítulos de historia cultural del reinado de Felipe II. Madrid; y CAMPOS, M ${ }^{a}$ D. y VIFORCOS, I. (1995). Honras fúnebres reales en el León del Antiguo Régimen. León.

Máxime cuando a esa idea se unía la de que: “¿quién dejará de querer bien a aquel de quien se esperan tantos bienes?”; ZABALETA, J. de (1653). Errores celebrados. Madrid.

43 "En los príncipes, que viven en quietud y comen y beben demasiado, la mayor parte de los dolores vienen... por su merecimiento, porque comen cuanto les viene en el apetito, no tienen regla y usan de buenos manjares, y más cuando no hacen ejercicio”; LOBERA DE ÁvILA, L. (1544). Libro de las quatro enfermedades cortesanas;... Toledo.

44 Bennassar, B. y Vincent, B. (2000). España en los Siglos de Oro. Barcelona, pp. 51-57.

45 MelgosA, Ó. op. cit., pp. 84-86; “A mayor gravedad, mayor intensidad de las rogativas en cantidad y calidad". 
mayoría de las ocasiones, aunque las oraciones populares no siempre clamaron por su pronta curación debido al 'secreto oficial'46.

Sólo un ejemplo ilustrativo de la trascendencia de los rituales funerarios regios. En septiembre de 1558, a Carlos V "le abate el sentimiento, pero también el rostro despiadado de la muerte, la certeza casi tangible de su presencia, su llegada inminente, no por esperada menos patética: le preocupa el saber de la muerte, su representación mental anticipada... conmocionado por la angustia que surge de su propia premonición" ${ }^{47}$. Con los “avisos de su debilidad, de su agotada resistencia, tenía el sendero último expedito: 'la muerte entre los dientes”,"48. Ya en agosto “porque esté prevenido de lo que pudiera suceder”, tan pronto como pudo, reunió a su confesor y a su secretario "para preparar el codicilo”. En él ratifica su testamento previo, propugna el exterminio de la herejía mediante el Santo Oficio e indica los detalles de su enterramiento en Yuste. Lee con frecuencia los salmos que más le impresionan: el de profundis; se confiesa tan a menudo como recita sus oraciones cotidianas; los monjes intensifican sus plegarias para su pronto restablecimiento total; "sus demonios personales también pasean con él”; noches de desvaríos y vómitos le llevaban a la comunión diaria. Nadie dudó entonces del muy cercano desenlace final del ya patético y flaco Emperador; máxime, cuando se le quitaron las ganas de comer. Acepta su agonía sin resistencia, entregado, consciente de su extrema gravedad ${ }^{49}$. El día 19 se le dio la extremaunción, y a las doce del día siguiente "bien entero de entendimiento, de su propio motivo pidió el santísimo sacramento, el cual fue administrado y recibido con toda la devoción posible, habiendo S. M. continuamente oído a los religiosos de su convento leerle los salmos y otras devociones;... plugo a Nuestro Señor llevarle de este mundo miserable a la vida eterna, y así expiró esta mañana del 21 a las dos dadas”. Y murió siguiendo al pie de la letra el paradigma ofrecido por Erasmo en su conocidísimo entonces Coloquio: enciende nueve velas blancas, cruza sobre su pecho el crucifijo, invoca a la divinidad, etc.

46 “Estaba ya todo prevenido en la Capilla Real para cuando Felipe IV pidiese el Viático... Preguntáronle si quería que le trujiesen en público o en secreto, y respondió que en público, porque quería que todos supiesen el estado de postración en que estaba y para que sus vasallos le encomendasen a Dios...”; CALDERÓN, E. (1991). El rey ha muerto. Cómo y de qué murieron los reyes de España, desde Fernando el Católico hasta Alfonso XIII. Madrid, p. 74.

${ }^{47}$ García Simón, A. (1995). El ocaso del Emperador. Madrid, p. 116.

${ }^{48}$ GARCíA, A. op. cit., pp. 127 y 129. Véanse: GACHARD, M. (1854). Retraite et mort de CharlesQuint au monastère de Yuste. Bruselas, I, p. 167; y ElIAS, N. (1987). La soledad de los moribundos. Madrid, p. 11.

${ }^{49}$ SAndoval, fray J. de (15??). Carlos V en Yuste. Madrid, pp. 493-499. 
"La manera de morir del Emperador es la escena capital de un cuadro lleno de detalles que alientan una guerra sorda y terrible. El miedo a la condenación cuaja en una obsesión enfermiza que le acompañará hasta la muerte”... expresión de la esencia de su tiempo, del sentido sacralizado de la época y aún de las posteriores más barrocas "arteramente dispuesta, de manera que cualquier iniciativa o necesidad humana no pueda eludir sus prescripciones, reglas, su vigilancia o supervisión, sus previsiones. Todo converge al fin en el terror a una gran inseguridad, a ese ejercicio de rascar en la trascendencia ultraterrena, ante la que los hombres sienten escalofríos... y les desazona hasta la extenuación la inseguridad de una salvación eterna que no terminan de ver garantizada en este mundo, del que partirán siempre angustiados. La gran paradoja de Carlos V será que, siguiendo criterios erasmianos en el buen morir cristiano, encabeza a la vez el repliegue humanista y el fanatismo de la intolerancia y la barbarie" ${ }^{\text {. }}$.

Según los jerónimos que le atendieron "los cielos se inflamaron mediante un cometa que fijó su núcleo y difusa cola justamente encima de Yuste, para estupefacción de los lugareños” (al igual que ocurrió a la muerte de la emperatriz, su mujer). "Y una azucena del huerto de su palacete abrió por fin su botón espléndido de pétalos blancos, que había negado a su habitual sazón allá por el mes de junio; y cuando su cuerpo se hallaba expuesto en la iglesia conventual, un gran pájaro, hasta entonces desconocido, se encaramó graznando en el terrado de la capilla mayor, repitiendo sus gritos en días sucesivos”. Los signos provenían del cielo, siendo interpretados inmediatamente como muestra palmaria "de intervención divina en la conclusión providencial de un ciclo vital”. "A hechura de Dios, de sus ministros -notarios del recorrido escatológico de las almas y expendedores exclusivos de vida inextinguible- y del hombre mundano" semejante instrumentalización también aseguraba la salvación eterna para aquel gran defensor del catolicismo militante, máxime después del supremo ejemplo -medieval y monacal- de su retiro contemplativo "huyendo de todas las nimiedades y alegrías del mundo" 51 .

50 GarCíA, A. op. cit., 'La muerte’, pp. 131-137; y 'Carranza en la muerte erasmiana del Emperador', pp. 139-147.

51 Ibidem, 'Epílogo a una certera salvación’, pp. 149-151. Todavía en 1582 el franciscano fray Luis González Méndez confesaba que “en el momento de su propia muerte había tenido una extraordinaria visión en la que asistió al juicio que en el cielo le hicieron a Carlos V, muy acusado por los demonios... aunque no había sido sino, por particular orden, ministro de la justicia divina. Y con esto se le llenó el rostro de alegría al emperador, y todos los ángeles adoraron a Dios en aquel secreto. Y muy contentos y alegres aventaron al demonio, y tomándole Dios por la mano le llevó consigo a su gloria”. Una muerte exaltada como claramente ortodoxa, en aquel momento de proceso acelerado de sacralización general: durante el auge barroco, cuando sus dogmas se extendieron, el poderoso aparato 
En el mismo sentido de definir claramente los rituales públicos de las muertes privilegiadas, el Ceremonial Funerario de la Catedral de Palencia de mediados del siglo XVI se reiteró apenas inalterado en todos sus capítulos a lo largo del Antiguo Régimen cada vez que se sucedían los fallecimientos de las autoridades diocesanas o de alguno de sus miembros ${ }^{52}$.

* En fin, como lo más odioso era el caos, el orden mental barroco era muy poco amigo de las novedades y siempre debía estar pendiente en cualquier acto de las etiquetas, las cortesías y las solemnidades. Se complacía en rituales y ceremonias. Su disfrute era universal, porque a todos les permitía mostrar públicamente sus preeminencias, aunque sólo fuese sobre la base efímera, pero memorable, "de haber sido vistos portando una candela en cierta procesión"53.

\section{VISIONES EXTRANJERAS SOBRE LA SACRALIZACIÓN BARRO- CA CASTELLANA}

En sus desplazamientos por la Castilla del siglo XVII, diferentes viajeros extranjeros también apreciaron, críticamente, la realidad espiritual de las tierras por las que pasaban ${ }^{54}$.

Joly, Sobieski y Bertaut se hacían eco de que la religiosidad española se basaba en las devociones derivadas de la veneración milagrera y de la consecución del favor divino. Por eso, en Alcalá tienen una imagen de la Virgen muy milagrosa y venerada: "lámparas de gran valor y muchos votos de plata cuelgan allí”; Nuestra Señora de la Almudena de Madrid "se halla con grandes y preciosos votos y

eclesiástico impregnó con rigor y disciplina las conciencias castellanas, 'salvadas’ por los católicos decretos de Trento. Véase: TellecheA, I. (1958). "Así murió el Emperador. La última jornada de Carlos V”, BRAH, no 143, pp. 155 y ss.

52 Consuetudinario o Ceremonial de la Santa Yglesia de Palencia, compilado por el canónigo de la misma don Juan De ArCE. 'Exequias y Honras Fúnebres'. Archivo de la Catedral de Palencia, Histórico, arm. IV, leg. 4, 833, 1550.

Funerales palentinos que jerarquizaban claramente el ceremonial a seguir durante las Ofrendas; el día de Honras; en el Septenario; en el Cabo de Año; o para las Ofrendas Anuales generales.

53 AlcalÁ-Zamora, J. op. cit., 'La cosmovisión del Siglo de Oro’, pp. 220-234. Véase: ARCO y GARAY, R. del (1941). La sociedad española en las obras dramáticas de Lope de Vega. Madrid, p. 447.

${ }^{54}$ García Mercadal, J. (1999). Viajes de extranjeros por España y Portugal, desde los tiempos más remotos hasta principios del siglo XX. Valladolid, 6 volúmenes.

Véanse también: MontAÑÉs, J. (1559). Espejo de bien vivir y para ayudar a bien morir (traduciendo once capítulos del tratado Ars Moriendi medieval). Valencia; CóRdOBA, M. de. Consuelo en la mayor pérdida en la muerte de Felipe IV; o GARCÉs, J. (1678). Ave María, la luz más clara, que deshace las tinieblas. Jaén. 
donativos colgados”,55; “en Illescas hay una Nuestra Señora que dicen haber hecho muchos milagros, y su iglesia está llena de exvotos y más de cien lámparas de plata”; o $\mathrm{N}^{\mathrm{a}}$ Señora de la Victoria de Málaga recibe "multitud de exvotos y gran devoción" 56 . Así, "las platerías eran distintas que en Francia: como son muy amigos de exvotos, sus tiendas están llenas de mil pequeñas figuras de pies, manos, brazos, piernas y otras locuras"

Cornwallis resumía certero aquella mentalidad barroca ${ }^{58}$ : "universalmente los españoles están muy inclinados a la religión y a la devoción, pero con tal grado de superstición y aptitud para creer en falsos milagros y fábulas fingidas de la santidad de cualquier persona que con este pensamiento y la extrema licenciosidad de sus vidas tienen una gran facilidad de disposición para caer en la herejía, si no estuvieren restringidos por el terrible Oficio de la Inquisición, que con gran razón se mantiene firme”. Menos crítico, también Sobieski, pintando el interior de las iglesias, recalcaba el carácter piadoso castellano: "la gente es muy devota y las iglesias están llenas. Los templos carecen de bancos; las mujeres se sientan en el suelo, unas en almohadas bordadas de oro y otras ponen cueros para sentarse, de modo que parece ricamente tapizado"; extendiendo tal celo al propio rey, quien: "en Madrid, desde el Corpus a la Asunción, asistía públicamente a las funciones de iglesia, y por la tarde todos los días a las procesiones, que se hacían con manifiesto del Santísimo Sacramento. Los embajadores de las potencias extranjeras y los más notables acompañaban siempre al monarca en sus ejercicios devotos”59.

Pinheiro señalaba que los vallisoletanos eran muy "espléndidos en mandar decir misas y pagar limosnas por ellas”, relatando la publicidad que hacían de sus muertes: "en los entierros se guarda la costumbre antigua de acompañar el viudo a la mujer hasta la sepultura. Cumplido el año y mes del fallecimiento llevan carneros, pellejos de vino y sacos de pan y los ponen encima de la sepultura; como esto se tolera hasta dentro de la misma iglesia, debe ser costumbre buena y bien arraigada en Castilla (en otras partes se manda dicha provisión a casa de la

55 García Mercadal, J. op. cit.; tomo III, siglo XVII, Jacobo Sobieski (1611), El Reino de España, polaco, pp. 185 y 186.

56 Ibidem; tomo III, siglo XVII, Francisco Bertaut (1659), Diario del Viaje de España, francés, pp. 431 y 452.

${ }^{57}$ Ibidem; tomo II, siglo XVII, Bartolomé Joly (1603-04), Viaje, consejero del rey, francés, p. 695.

${ }^{58}$ Sir Charles Cornwallis (1608), Discurso sobre el Estado de España, inglés; en SANZ CAMAÑES, P. (coord.) (2005). La Monarquía Hispánica en tiempos del Quijote. Madrid, p. 84.

59 García Mercadal, J. op. cit.; tomo III, siglo XVII, Jacobo Sobieski (1611), El Reino de España, polaco, pp. 186-187. 
difunta). No hay en los entierros lloros ni lamentos. 'Los muertos al hoyo, los vivos a la olla', esto dicho con la modestia y sufrimiento del buen cristiano me parece muy preferible a los disfraces, fingimientos y desmayos de que ordinariamente se usa. Los hombres no gastan capuz de duelo sino treinta días después del fallecimiento; sombreros forrados sin velo, luego lechuguillas y cuellos abiertos, paño oscuro; las mujeres, tocas de dueña o moños con crestas; una viuda decía: 'yo venderé la saya por llevarle a la sepultura y el manto por levantarle de la cama; pues lo que deseo es mi reposo y no su muerte",60. Y tan hondo había calado la necesidad de redactar últimas voluntades que cuando un amigo suyo se despedía de Valladolid para regresar a su Lisboa natal utilizaba las "cláusulas del codicilo que otorgó tras el testamento que hizo”61.

La clara ambivalencia religiosa que muestra el relato del cardenal de Retz es magistral, al asegurar haber vivido personalmente que "durante una borrasca marítima todo el mundo estaba rezando y se confesaba, y tan sólo don Fernando Carrillo, que comulgaba todos los días y que era de una piedad angélica, dejó de arrojarse a los pies de los sacerdotes con prisa: 'temo mucho [afirmaba] que todas estas confesiones, que sólo el miedo produce, no valgan nada,’,62.

Eran, en palabras de Muret, 'especias de la devoción española': pues “a una ejecución pública femenina asistieron todos los grandes como a un maravilloso espectáculo. Los balcones de la Plaza Mayor estaban cargados de gente, que nunca se vieron más en las corridas de toros. Era llevada al suplicio por doce religiosos, que hicieron su exhortación particular. Tan bien persuadieron al pueblo de que moría como una santa que durante todo el día hubo furiosa prisa por besarle los pies y la cuerda fue hecha cien mil pedazos conservados como reliquias”63. Y en

${ }^{60}$ Ibidem; tomo II, siglo XVII, Tomé Pinheiro da Veiga (1603), Fastiginia o Fastos Geniales. La Corte de Felipe III. Pincigraphia, Descripción Moral de Valladolid, caballero, portugués, pp. 774776.

61 “Considerando que no me es ya posible dilatar por más tiempo este último trance en que me hallo; sabiendo yo que voy ya caminando para aquel valle de lágrimas donde no se hace más que gemir y llorar, y que habré de hallarme pronto en presencia de Dios, en aquel universal y terrible trance del Juicio Final; allí donde de todos mis pasos habré de dar cuenta y residencia, y donde a todos se les ha de tomar estrecha cuenta de sus pecados...”; Ibidem, p. 786.

${ }^{62}$ Ibidem; tomo III, siglo XVII, cardenal de Retz (1654), Memorias. Viaje por España, francés, p. 251.

63 Ibidem; tomo III, siglo XVII, Juan Muret (1666-67), Cartas escritas desde Madrid, predicador, francés, p. 562. 
las de Jouvin: 'un alarde más exterior y ceremonial de la devoción de las buenas gentes ${ }^{64}$.

Entre las 'rarezas religiosas nacionales más criticables' algunos extranjeros destacaron las siguientes: "Los frailes de Burgos guardan en su convento un crucifijo de plata que presentan a los transeúntes para besar, y al mismo tiempo el plato para recibir la limosna. Como no estamos acostumbrados a esa doble acción de llevar los labios a un sitio, donde no se sabe quién ha frotado su hocico, y llevarnos la mano a la bolsa, nos apartamos de aquel pequeño Dios de plata que nos habían ya puesto bajo la nariz. Estaban escandalizados, pero en nuestro país no se lo presentan más que a los que iban a colgar o a los que estaban a punto de morir. Esto no les parecía de buenos cristianos, porque la gente es aquí mucho más supersticiosa y menos ilustrada que en Italia; hasta el extremo de que en un sitio que no saludamos a las cruces de los caminos nos gritaron que no éramos cristianos. En sus imágenes pintan a Jesucristo y a los santos con un rostro de español, y espero encontrar alguna Virgen que hayan vestido con un verdugado"65.

"En las vísperas de las grandes fiestas van por las calles y encrucijadas cubiertos con un cilicio, destrozándose las espaldas con la disciplina, de tal manera que la sangre chorrea"66.

"Si los regocijos públicos que los moros introdujeron han quedado en España después de echarlos, la Iglesia también ha retenido algo de su superstición en la fiesta de Dios, que llaman del Corpus. Vimos todas sus ceremonias; y no hay otras que llevando tras sí tanta gente duren más tiempo. La comienzan por una procesión cuyas primeras filas van entremezcladas de oboes, gran cantidad de tamboriles y castañuelas. Se ve un pelotón de varias personas vestidas de diversos colores, que al son de esos instrumentos van bailando, saltando y dando brincos, con tanta chunga como si estuvieran en el carnaval",67. Asimismo "hacen otras procesiones al ruido del tambor y de cincuenta campanillas, que los niños sonaban con

${ }^{64}$ Ibidem; tomo III, siglo XVII, A. Jouvin (1672), El Viaje de España y Portugal, francés, p. 601.

${ }^{65}$ Ibidem; tomo III, siglo XVII, Antonio de Brunel (1665), Viaje de España, francés al servicio holandés, pp. 259-260.

"Es forzoso que a los trabajos de los labradores se les recrezca la carga de tantas demandas, dando muchas veces limosnas más por pundonor que por devoción”; BN, ms. 10930 (siglo XVII), Papeles curiosos manuscritos.

${ }^{66}$ Ibidem; tomo III, siglo XVII, A. Jouvin (1672), El Viaje de España y Portugal, francés, p. 583.

${ }^{67}$ Ibidem; tomo III, siglo XVII, Antonio de Brunel (1665), Viaje de España, francés, p. 290. 
todas sus fuerzas, provocando un ruido tan espantable que yo no podía ver nada más que la boca de los sacerdotes abierta",68.

Y, en Madrid, “cuidan más a las damas cuando han muerto que en sus enfermedades" ${ }^{\text {69 }}$.

Sin embargo, juzgaban como 'muy eficaces' algunas otras 'modas funerarias hispanas’.

"Rezan cuidadosamente por las almas del purgatorio, por las que piden en todas las iglesias, en las encrucijadas y en las plazas públicas, y a las nueve de la noche tocan la campana, y a eso se llama las ánimas, para rezar a Dios por sus benditas almas; y al mismo tiempo van por las calles pidiendo limosna. Además, cuando llevan a $N^{o}$ Señor a algún enfermo, ordinariamente por la noche, lo hacen con un séquito de casi todas las personas de calidad, cada cual con una vela en la mano, y hasta los que transitan lo acompañan, tanto que parece una procesión, seguida de un concierto de toda suerte de instrumentos, que va delante del Santo Sacramento; se detienen en todas las encrucijadas por donde pasa, hasta que ha llegado a la casa del postrado, desde donde vuelve con el mismo orden; lo que no es posible alabar bastante a los españoles. Y cuando llevan a alguno a enterrar, lleva el rostro descubierto, teniendo en su mano un cirio en forma de cruz; y si es hombre que no ha dejado medios bastantes, van al borde del camino, y en los cruces donde los sacerdotes se detienen, cantan el 'de profundis' y otras oraciones, durante cuyo tiempo van las gentes que piden por las casas con qué enterrarlo y rogar a Dios por él" "70.

"Don Juan de Austria se sintió tan agobiado por su enfermedad que le desahuciaron los médicos, haciéndole comprender que debía prepararse para la muerte. Recibió la noticia con una tranquilidad y resignación que contribuyeron a convencer a todos de que prefería la muerte a la vida: tal es el destino de los príncipes, igual que el de las personas ordinarias. Al día siguiente de fallecer ya no se hablaba de él, y parecía que jamás hubiese existido en el mundo"71.

68 Ibidem; tomo III, siglo XVII, Juan Muret (1666-67), Cartas escritas desde Madrid, predicador, francés, p. 549.

69 Ibidem; tomo III, siglo XVII, marquesa de Villars (1679-80), Cartas a la sra. de Coulanges, francesa, p. 694.

${ }^{70}$ Ibidem; tomo III, siglo XVII, A. Jouvin (1672), El Viaje de España y Portugal, francés, pp. 582-583.

${ }^{71}$ Ibidem; tomo IV, siglo XVII, madame d'Aulnoy (1679-81), Relación del Viaje de España, francesa, pp. 165-166. 
"Los sabios antiguos desaprobaron siempre las lágrimas que se vierten sobre los cuerpos muertos, sosteniendo que más bien debieran llorar el día del nacimiento que aquel que pone fin a todos nuestros trabajos. Los españoles hacen, más o menos, lo mismo. Verdad es que no se ponen luto cuando se convierten en padres, pero tampoco lloran casi la muerte de sus parientes; los hacen enterrar al son de los instrumentos y con conciertos de música, a los que invitan a la gente como a una fiesta. No hay nada tan agradable. No sólo la iglesia está tendida de negro en las paredes, sino que hay también gruesas alfombras por el suelo que se extienden hasta la puerta. El cuerpo está en medio del coro, con una docena de candelabros de plata de la altura de un hombre, todo alrededor, e infinidad de pequeños [he contado hasta trescientos] en el espacio que queda vacío y sobre el féretro. En el fondo hay tres filas de religiosos y sobre las graderías del altar mayor otra media docena de frailecillos, que son los llorones. Toda esa asamblea mantiene su gravedad mientras los músicos arman su alboroto. Después, llevan el cadáver a una capilla baja y subterránea, la cual no deja de estar tan alumbrada como la iglesia, perfectamente enlosada de hermosa piedra y ladrillo y los muros blancos (donde introducen los féretros, que inmediatamente cubren con yeso y escriben encima en letra negra el nombre del difunto). En verdad que no se puede ver nada más limpio, y si estuviera un poco menos agarrado a la vida eso me haría desear morir en España para tener una sepultura parecida, en vez de que en Francia no podemos esperar más que cinco o seis pies de tierra sobre el cuerpo, lo que no parece contribuir poco al horror de la muerte. Tuve la curiosidad al día siguiente de Todos los Santos de ir a visitar asas capillas subterráneas en todos los conventos y parroquias de Madrid"

Finalmente, así transmitía Bassompierre a la corte gala la 'Relación de la enfermedad y muerte de Felipe III'. “El rey católico estuvo en la capilla el domingo. Después de haber oído misa y sermón volvió la fiebre. Sufrió una gran melancolía de opinión de morir, por la que decía que bien veía que se moría. ¡En jornada tan larga y tiempo tan breve no era menester reposar!. Mandó que trasladasen la imagen de Nuestra Señora de Atocha a las Descalzas, lo que hicieron con una gran procesión, a la que asistieron los Consejos; y por la noche ordenaron a las iglesias que expusieran sobre los altares el Santo Sacramento y que llevasen a palacio el cuerpo de san Isidro. Llegó su confesor, y ante los gentileshombres de cámara firmó su testamento, que el secretario de estado había escrito en su presencia”. Gritó a la infanta: "que pena siento de morir sin haberte casado; tu hermano cuidará de ello”; y al príncipe: "no la dejéis hasta que no la hagáis

\footnotetext{
${ }^{72}$ Ibidem; tomo III, siglo XVII, Juan Muret (1666-67), Cartas escritas desde Madrid, predicador, francés, p. 553.
} 
emperatriz”. Mostró un gran sentimiento al no poder despedirse de la princesa. Pasó luego a repartir reliquias y otras cosas particulares, salvo un crucifijo que estaba colgado a la cabecera de la cama "porque era aquel con el que su abuelo y su padre habían muerto, al que los papas habían concedido grandes indulgencias; y también moría con él, que le recomendaba [al príncipe] servirlo con reverencia después de su muerte”. Dio a todos su bendición, “les hizo salir, y habiendo pedido la comunión le fue dada a eso de la medianoche, y el martes día 30 recibió la extremaunción a las diez de la mañana; después hizo recomendar su alma. No dejó por eso de firmar gran cantidad de papeles... Al mediodía pusieron el cuerpo de san Isidro cerca de su cama, y un fraile le encomendó que hiciese voto de construir una capilla al dicho santo, lo que hizo”. Pidió también que su cuerpo no fuese abierto después de su muerte. Hicieron muchas procesiones de penitentes por la ciudad, pero desde por la mañana del último de marzo ya se publicó su fallecimiento, aunque éste no fue hasta cerca de las nueve. Lo cierto es que ya había sido anunciado desde los cielos: “el cometa de que bromeábamos no era para tomarlo a burla, pues ha puesto en tierra en dos meses un papa, un gran duque y un rey de España; este último acababa de expirar tan santamente que si, después de los largos años que con toda prosperidad os deseo, hacéis un fin parecido habréis tenido el colmo de la dicha en todos los mundos"73.

73 Ibidem; tomo III, siglo XVII, mariscal de Bassompierre (1621), Embajada a España, francés, pp. 215-218.

Otro ritual funerario regio posterior: "A las ocho de la noche del viernes llevaron el cuerpo del infantito a El Escorial. Vi el aparato de la salida de su cadáver, que era de unos cincuenta guardias a caballo. Había también un mayordomo y algunos gentileshombres de boca; y alrededor de cuarenta frailes sobre mulas, cada uno con un cirio de cera blanca. El cadáver lo pusieron en un cofre sujeto sobre unas parihuelas cubiertas de tisú de plata, llevadas por dos mulas todas cubiertas de caparazones de tisú de plata. En las cuatro esquinas había cuatro faroles de vidrio llenos de velas. El sábado por la mañana, ciento cincuenta religiosos, aproximadamente, le salieron a recibir en El Escorial. Lo llevaron al panteón, que es el lugar destinado para su sepultura. Allí el prior quiso ver el cuerpo, e hizo jurar al mayordomo que era el del infante, como es la costumbre; de otro modo no lo recibiría. Todos los embajadores sondearon si serían recibidos para hacer su cumplimiento de condolencia sobre aquella muerte. Nadie se vistió de luto en la corte, diciendo el mismo rey que era preciso no mezclar la tristeza entre la alegría de la paz y de un matrimonio"; Ibidem; tomo III, siglo XVII, Francisco Bertaut (1659), Diario del Viaje de España, francés, pp. 406-407.

Y un tercero [entierro de la hija del duque de Medinaceli]: "Su féretro era de una madera preciosa de las indias, puesta en un saco de terciopelo azul, cruzado de bandas de muaré, cordones de hilo y borlas. Era llevado en un carro cubierto de terciopelo blanco, con festones y coronas de flores artificiales todo alrededor. Ordinariamente visten a los muertos con los hábitos de alguna orden religiosa (a las mujeres ponen el de las carmelitas, que goza aquí de gran veneración), y los llevan con el rostro descubierto hasta la iglesia donde son inhumados"; Ibidem; tomo IV, siglo XVII, madame d‘Aulnoy (1679-81), Relación del Viaje de España, francesa, p. 109. 
En definitiva, y como bien mostraba la teatralidad de la peligrosa aventura del Quijote en la que Angulo el Malo viajaba disfrazado de diablo, su éxito se basaba en el auge popular de los 'Autos de las Cortes de la Muerte' (II, XXII); pero tampoco olvidemos su sentencia: "hase de usar con la honesta mujer el estilo que con las reliquias: adornarlas y no tocarlas” (I, XXXIII).

De igual manera que, mediado el siglo XVIII, los propios españoles también alentaban ya la reforma de los comportamientos sacros más habituales de los castellanos. Dialogando con fray Gerundio un familiar de la Inquisición era tajante entonces ${ }^{74}$ : “decirme a mí c'ha de ser inculto y ensequio de los santos traer unos hábitos que cuestan más que las galas de una novia, sólo porque se asemejan un si es en el color; pero en lo demás mucho cintajo y farfala, franja, cabos y güeltas por aquí y allá, y ansina otras fantasías c'ha inventado la vanidad de las mujeres. Esto más es bulra que devoción, más es inritar a los santos que hacérnoslos prespicios” (“¡de seda!, ¡de telas d’oro y prata!, ¡mucho encaje, perifollo y sí, señor! Déjelo padre; que ése es un lurdibrio de la religión; y no sé yo como no han metido en esto la mano los que pueden atajar estos escarnios"). "Ni es divoción, ni pinitencia, ni muertificación, ni molestia sino ventolera, estintación, porfanidad, descarnio, sacrilegio y qué sé yo qué más”. “A pocos días c’anduvo con este traje enresible para los hombres de juicio, la Virgen dejó de sanarle y volvió a enfermar”.

Según el mismo pasaje, en el uso de hábitos religiosos como 'especie de mala moda': "se visten así no más que por antojo y por envinción de su loca fantasía. Las nazarenas usan de este vestido por pura vanidá, y no parece sino que se valen de él para ser más desenvolvidas. Y poco más o menos lo mismo que digo de ellas lo aprico también a las demás que traen hábitos galanos. Por ahora, no me opongo a que las solteras percuren líncitamente agradar a los hombres, y engalanarse para esto cada una según sus pusibres. Su alma, su palma; pues para las mujeres los tres enemigos son: el dimonio, el mundo, la carne y el deseo de parecer bien”.

\footnotetext{
${ }^{74}$ IsLA, padre J. de (1978). Historia del famoso predicador Fray Gerundio de Campazas. Madrid, Luis Fernández ed., 2 tomos. II, pp. 780-791. "Discusión con un familiar de la Inquisición”.
} 


\section{CRÍTICA SOCIAL Y CERTIDUMBRE DE LA MUERTE: TESTA- MENTO DE UN POBRE, QUE YA SE CANSÓ DE SERLO Y HUYENDO DEL MUNDO, DEMONIO Y CARNE, SE QUIERE MORIR POR NO VER MUCHAS COSAS ${ }^{75}$}

En un tono jocoso e irónico, acudiendo a la versificación y desde el anonimato, aparecieron durante el Antiguo Régimen diversos escritos que ponían de manifiesto la visión que la cultura 'popular' tenía sobre el complejo entramado socioeconómico que envolvía sus vivencias y su mundo de pobreza terrena y de aspiraciones sobrenaturales en la última hora de sus vidas.

Un exponente de ese género literario satírico tan extendido en el siglo XVII ${ }^{76}$ es este Romance anónimo. Bucearemos en los valores culturales desprendidos de su lectura histórica.

Un autocalificado 'pobre desengañado' relata al final de sus días el 'sentido' de toda su vida, resumen de las vivencias de un amplio colectivo ante la importancia de las desigualdades económicas intensificadas en el momento trascendente de la salvación eterna personal ${ }^{77}$.

Se trata de un testamento; un documento jurídico de últimas voluntades considerado capital para "ponerse a bien con Dios" en los instantes postreros. Siendo personal, refleja planteamientos colectivos ante la muerte, al encarnar un ritual asumido popularmente. Este ejemplo, por ello más interesante, no es el tópico notarial: sigue su estilo típico, pero con un lenguaje, unos sentimientos y una percepción de 'su pícara realidad' que lo convierten en único a la vez que representativo de los comportamientos generales. Resaltamos la similituddiferencia de este texto limeño respecto a los protocolizados, sobre unas mismas actitudes trascendentes (de vida y hacia el más allá).

75 Testamento, codicilo y última voluntad... ; BN, ms. 10952. Papeles curiosos, t. 67, pp. 52-63. Lima, sin fechar.

${ }^{76}$ Versificaciones recopiladas en la obra de EGIDO, T. (1973). Sátiras políticas de la España Moderna. Madrid.

${ }^{77}$ Varios puntos de interés surgen de la lectura de este escrito anónimo y no fechado. Se sitúa después de la publicación del Quijote; el autor llegó a Lima con 'la Visita'; alude a Nueva España y a Lima; y dice conocer las novelas y comedias de Zayas (en referencia a María de Zayas y Sotomayor, nacida en Madrid en 1590 y fallecida en 1650). Por todos estos datos nos atrevernos a fechar esta obra en la segunda mitad del Seiscientos; y a afirmar que fue escrita por un 'desconocido': 'culto pero pobre’ y miembro ‘mediano’ de la administración española en América. 
Ofrece una crítica generalizada a todos los valores que han llevado a su autor a padecer la precaria situación en la que se encuentra. En rápido catálogo: la envidia, la adulación, la falsedad, los 'ladrones ricos', todo lo que es fachada y apariencia, el 'vales cuanto tienes', la juventud (ante todo lo malo que trae consigo la vejez), el 'al que no da le despachan', los robos y 'fortunas extrañas', la necedad, la adulación, el 'falso amor' y el que nadie ose 'emplumar' a los poderosos. Critica a los barberos, a los escribanos, a los cocineros...; y parece que sólo aprecia a las mujeres jóvenes y 'de sangre liviana'. En definitiva, todo lo que le ha frenado estar en la cumbre y quienes le han impedido 'gozar de los lujos de la vida' son irónica y despectivamente caracterizados ${ }^{78}$.

No está conforme con su mundo 'trastornado'; palabras y acciones nunca coinciden, para perjuicio de los más débiles. Todos procuran 'subirse a las barbas' de los demás y se trata mejor a los que tienen 'pelo' que a los 'pelados'. Por eso triunfan como virtudes la falacia ('las verdades amargan'), la picaresca, la mentira y el aparentar. El 'tener y ostentar' ('porque al que no da le despachan') y casar bien con mujer guapa (Dulcinea aprovecha los cortejos) ocultaban la necedad.

La palabra clave es pobreza. Vivencias que eran la base para el otro argumento clave del relato: la cotidianidad de la muerte. 'Enfadado de vivir', quiere 'morirse de buena gana' ('los desengaños matan'), dado que sólo los poderosos pueden sentir dejar esta vida y sus riquezas ${ }^{79}$ :

Morir es fuerza, la muerte no me puede ser ingrata muera de una vez un pobre que está muriendo de tantas.

Que el salto a la eternidad viene a ser una barranca que en no cogiendo carrera
Yo quiero una muerte justa y abandonando las anchas una que me venga bien y no vaya yo a buscarla.

\begin{tabular}{ll}
\hline $78 \quad$ Que empluman a un alcahuete \\
por no tener quien le valga \\
y se acabarán las plumas \\
si a todos los emplumaran. \\
Que el cariño y el aprecio \\
en las mujeres se acaba \\
y el cuento de los cortejos \\
suele parar en que para. \\
Dejo todo cuanto dejo \\
pues en esta vida humana \\
algunos dejan las cosas \\
porque no pueden llevarlas.
\end{tabular}


con gran peligro se salta.

Epitafio (349-356):

Bajo de esta losa fría

caliente, tibia o templada

yacen las cenizas muertas

de un pobre que vivió en brasas.

Contempla pues caminante

detente un poco y aguarda

y si acaso estás de prisa

vete mucho en hora mala.

Si algo hay seguro en esta vida es, sin duda, la certidumbre de morir. El momento exacto es lo que desconocen los hombres. Eso no importaba a un pobre que no podía disfrutar de ninguno de sus placeres. De lo que estaba convencida toda aquella sociedad es que no debía ser violenta y sin preparación previa. No podía ser ingrata, sino 'justa’: "una buena muerte”.

El 'salto a la Eternidad' debía prevenirse utilizando todos los medios propuestos por la Iglesia: la ‘carrera para la salvación' conduciría a las penas infernales o a la gloria eterna individual, pero toda la sociedad 'se contempla' en cada fallecido, al ser, para aquellas mentalidades, una verdad universalmente reconocida ${ }^{80}$. Por eso, el testamento era un documento muy significativo para valorar las actitudes y comportamientos de la población ante el instante crucial postrero.

La visión personal de este Romance anima a buscar planteamientos universales y aspectos únicos. En los últimos instantes vitales, "sintetizando apresuradamente temores y creencias, pánicos y esperanzas que presiden un tránsito organizado" se debían solventar los problemas "de conciencia” por todos los medios. Por lo que conceptos como: la seguridad de la muerte que a todos alcanza e iguala, la desconfianza en el hombre, la sabiduría de la vejez (ante la cercanía de la muerte que abre los ojos)... y la preocupación por el 'sexo débil', siempre estaban presentes.

80

Suplico a cuantos me miren

contemplen bien en mi cara

que lo que hoy se mira en mi

se verá en ellos mañana.

${ }^{81}$ RodRíGUez SÁNCHEZ, Á (1980). Morir en Extremadura. Una primera aproximación. Morir en la horca a finales del Antiguo Régimen (1792-1909). Cáceres, p. 11. 
Su valor religioso y redentor era innegable. Más de la mitad de las cláusulas testamentarias, la primera parte, se centraba en invocaciones a la divinidad, confesión de las verdades que profesa la Santa Madre Iglesia, petición de intercesores que aboguen por el perdón de mis "muchas culpas y pecados, lleven mi alma a su eterna gloria y enderecen esta mi disposición a mayor honra y gloria de Nuestro Señor”, encomendación del alma a Dios y del cuerpo a la tierra, disposición de todos los puntos concernientes al enterramiento del cadáver (asistencia al sepelio, hábito usado como mortaja, lugar de sepultura, etc.) y señalamiento del número, precio y lugar de celebración de las misas post-mortem, de cuerpo presente y del alma, bulas de difuntos, ofrendas funerarias, aniversarios, capellanías, fundaciones perpetuas, cabos de año y mandas pías.

En sus disposiciones se aprecian creencias religiosas, ritos de paso y actitudes sociales. Conductas -miedos y deseos de salvación- y prácticas culturales y rituales exteriorizados en el momento 'bisagra' de la muerte, se plasmaban en esas escrituras, reflejando los sentimientos individuales y colectivamente asumidos y la sacralización general, y trasluciendo los hábitos religiosos vividos en el instante crucial de la inminencia del óbito. Gran parte del mundo mental de la religiosidad popular se exteriorizaba entonces bajo fórmulas personalísimas pero estereotipadas.

Además, expresaban una clara jerarquización de comportamientos. Actitudes colectivas ante la muerte que muestran prioridades y una conciliación de intereses económicos y espirituales. Las consideraciones materiales eran fundamentales, pero aparecían entonces supeditadas al fin supraterrenal que presidía y organizaba la vida: la consecución y ‘compra’ de la salvación.

Dejar arregladas las cosas terrenales, estar prevenido para cuando la certera muerte llegase, solucionar lo mundano para únicamente emplear el tiempo en 'lo Divino', conseguir el perdón de los pecados, descargar la conciencia y lograr la perfección de las "cosas de cuidado" en momento tan crucial, siempre pensando en el "fuerte paso en que estoy", fueron las causas que inducían a testar, formuladas según un modelo muy extendido, y que también reflejada este Romance.

Los aspectos y alusiones religiosas, ahora con un fuerte tono sarcástico, llenan los versos 145-184. Cree que todas las almas fueron redimidas por Cristo y en las verdades defendidas por la Iglesia católica (¡ay de aquel que desconfíe de la existencia del Infierno: 'verá allá lo que pasa’!).

Y como un testamento notarial más, fija todas las condiciones que debe reunir su funeral y enterramiento. Entre otras cosas, la mortaja religiosa (el demandado hábito pardo franciscano) si bien en este caso nuestro personaje se conforma, al 
haber perdido las esperanzas, con una camisa de su uso diario: vieja y negra; una sepultura bajo tierra (ataúd $=$ arpa), aunque desconfiara del trabajo de algunos enterradores; y todavía más del cortejo que debía acompañarle hasta la tumba.

Clérigos, música, pobres y 'lloronas’ nunca debían faltar en un sepelio 'decente'. Siendo imprescindibles, el autor satirizaba tales compañías: el clero no 'robe' ni cobre tanto por sus oficios mortuorios ('de mi no toque nada'); la luz (la cera, las hachas), símbolo de vida eterna, contrastaban con el negro luctuoso, y más siendo portado por personas de color; y de entre los muchos pordioseros, prefería beneficiar a los más próximos. En conclusión, no quería ser llorado ni recordado durante su último acto público: “pues es locura llorar / cuando los clérigos cantan”.

Otros argumentos completan estas preocupaciones funerarias y religiosoeclesiásticas. El toque de campanas (prefería el sencillo al doble), las velas (tampoco muchas, pues costaban), las misas por la salvación de su alma (siempre presentes en cualquier testamento, por muy pobre que fuese el otorgante) y una postrera encomendación a la divinidad, nunca podían descuidarse:

Encargo que no me doblen porque en todas circunstancias los sencillos son tratables pero los dobles son maulas.

Que me encomienden a Dios los sujetos de la farsa que en la comedia del mundo esta es la última jornada.

\author{
Suplico me digan misas \\ o cantadas o rezadas \\ también algunos responsos \\ aunque de estos no me faltan.
}

Tras estas consideraciones, entraba rápidamente a detallar una serie de recomendaciones vitales de última hora, varias declaraciones personales y familiares y todo el amplio elenco 'jocoso' de sus mandas testamentarias. La crítica social planeaba, de nuevo, jugosa, sobre estos párrafos.

'Donde no hay dinero / no son forzosas las mandas', pero: barajas, tonadas, guitarra, violín, espadín, tintero, bolsas, navaja, petacas, colchón y casaca (sus objetos preciados) fueron donados a: amigos, 'gente de Jauja', tonadilleros, ladrones, enfermeros, sangradores, barberos y escribanos.

Mandas todas muy poco desinteresadas. El espadín a un ladrón, con el fin de que muera con él; un colchón para alguien que vivía de sueños; la guitarra sin cuerdas la recibiría su enfermero para sólo usarla como adorno; a sus amigos escribientes legaba un tintero carente de pluma; a los escribanos profesionales fuertes críticas, además de un violín; una baraja para los 'falsos que juegan a dos caras'... Los únicos beneficiados realmente fueron un sangrador con sus navajas, 
un pobre al recibir su casaca negra, y ese 'grande aficionado' que se deleitaría con su librito de tonadas.

Concluía ironizando sobre las 'frecuentes rapiñas' producidas tras muchos decesos:

Que no me llore Bélica

Teresita o tía Juana

pues muchos lloran al muerto

porque se acabó la papa.

Cual se agarra una camisa y cual se esconde una almohada y aun tal vez suele el servicio no estar libre de sus garras.

Dejo tenedor de bienes a uno de mi confianza que muchos quisieran ser tenedores, no cucharas.
Entre lágrimas y moca andan viendo lo que ganan y con lo que está en el cielo todo cuanto topan, tragan.

No quiero que haya convites pastelones, ni viandas no es razón uno esté muerto mientras otros se regalan.

Otros aspectos de diversa índole también salpican el relato. Entre los más señeros sobresalen los de carácter 'artístico' y el omnipresente relacionado con su 'pasión’ por las mujeres.

Frases como: 'dar música / el tocar y cantar áreas', 'ninfas', arpa, músicos, chanzas, Jauja, guitarra, tintero sin pluma, violín, novelas, comedias, Dulcinea y Sancho Panza, Barataria, mandar libritos de tonadas o Zayas ayudan a mostrar el carácter del autor. Las vertientes literaria (poesía, básicamente) y musical definían sus inquietudes. Había leído a Cervantes, pero también gustaba de componer poemas, de los que se complace y creía 'no malos'.

En la misma línea, apreciaba y disfrutaba de la farándula limeña. Músicos y 'Jauja' acompañaban sus penurias económicas y las hacían (hasta su muerte) más llevaderas.

Que me encomienden a Dios los sujetos de la farsa que en la comedia del mundo esta es la última jornada.

Por último, reseñamos su visión del sexo femenino. 'Aunque todas eran unas interesadas ${ }^{82}$ y aún convencido del gran poder de su belleza y juventud, las

82 “pues muchas lloran al muerto / porque se acabó la papa”.

"todo cuanto topan, tragan". 
necesitaba: su único sufrimiento al salir de este mundo era que 'siente mucho dejarlas'. Sus versos confirman tales aseveraciones:

Dejo a todas las vecinas

de la parroquia en sus casas

$y$ si he de decir verdad

no siento poco el dejarlas.

"y por doña Dulcinea / se hace rico Sancho-Panza".

\section{CONCLUSIONES: CONTROL DE LA MUERTE, RITUAL FUNERARIO Y SOLIDARIDAD EN EL MÁS ALLÁ}

Durante el largo periodo barroco, frente a las novedades ilustradas, la religiosidad popular estructuraba por completo el universo mental castellano: sus comportamientos y actitudes así lo confirman. Toda aquella sacralización vivencial tomaba aún mayor vigencia cuando la asiduidad de la muerte se presentaba en el seno familiar, se comunicaba inmediatamente a todo el vecindario y rápidamente también concitaba a clérigos, niños, cofradías y pobres a la puerta de las moradas funerarias, para iniciar desde allí el traslado procesional postrero hasta las puertas de parroquias y cementerios eclesiásticos ${ }^{83}$.

La muerte estaba ritualizada en la sacralizada sociedad del XVII. El duelo era público. Se tendía a la codificación del aparato funerario. Ante la preocupación colectiva que generaba (y más la espectacular, aleccionadora y ejemplar) los cambios producidos en la mentalidad y en los comportamientos, y en las visiones y actitudes generales vividos en el momento del tránsito, sólo son apreciables en la larga duración. Diariamente se presentaba como una realidad cotidiana y, por tanto, asumida con naturalidad, aunque el temor obligase a la alerta constante. Tema de reflexión frecuente, fue un recurso capital utilizado por la Iglesia como mecanismo de adoctrinamiento ${ }^{84}$.

Así, los moralistas recomendaban la redacción testamentaria mientras se gozase de buena salud: ante "lance tan terrible" y para lograr la meta de "la carrera de la gloria”. No obstante, sólo se testaba tras el agravamiento de la enfermedad final.

83 EgIDO, T. (1984). "La religiosidad colectiva de los vallisoletanos". En Valladolid en el siglo XVIII (t. V de la Historia de Valladolid, ed. Ateneo), Valladolid, pp. 159-244; TorREMOCHA, M. (2003). Solidaridad en el más allá. La Cofradía Sacramental y de Ánimas de la iglesia de la Magdalena de Valladolid. Valladolid; y GARCía FERnÁNDEZ, M. (2004). "De cara a la salvación en la España del Antiguo Régimen. 'La solución de los problemas temporales y de conciencia’”. En La Religiosidad Popular y Almería. Almería, pp. 41-67.

84 ARIÈs, Ph. (1983). El hombre ante la muerte. Madrid; "La hora de la muerte. Memoria de una vida”, pp. 87-140. 
Por eso reflejan una "buena muerte": en la cama, acompañada, rezada y protegida. Mientras, los sermones fúnebres muestran la visión oficial sobre los momentos postreros. Calavera en mano, diferenciaban la bondad del justo de la atroz tristeza del malvado, incitando a reflexionar sobre el averno, a cambiar de vida y a arrepentirse; insistiendo en la necesidad de prevención mediante una vida ajustada $^{85}$. "Pongas los medios para salir con bien, que de este modo será tránsito a mejor” resumía aquellos sentimientos: prepararse para lograr la 'muerte suave' y "que se note" dicha bondad, pues "el prestigio de la vida se establece en su fin; dependiendo la salvación del modo en que se moría”,

Ante la idea del Purgatorio ${ }^{87}$, la 'buena vida' obligaba a controlar su fin mediante 'pechos de entrada y sistemas de seguro', reforzando el carácter tanático y terrorífico de aquella religiosidad, pues en el camino a las postrimerías los 'espíritus buenos' ayudaban a evitar a los enemigos del alma: "cada uno tiene diputado su ángel de la guarda que le defienda de los lazos y tentaciones del demonio, las sujeciones de la carne y las pompas y vanidades del mundo”.

En dicho proceso, el juicio personal y final generaban pánico. De su resultado dependían las alegrías o tormentos eternos. La Iglesia controlaba aquellos miedos mediante un amplio sistema de méritos ritualizados. Exequias, honras y sufragios tenían como misión la consecución de la salvación o una menor demora intermedia en el Purgatorio, fundamentada precisamente en el arraigo de la creencia colectiva en dicho espacio y justificando todo el ritual que rodeaba la muerte.

Lo peor era morir solo y sin ceremonial. De ahí su socialización y clericalización, y la codificación del ritual funerario: los 'gestos' de la muerte se ‘veían', se 'olían’ y se ‘oían'. Estaba 'controlada culturalmente'. Dentro de unos moldes fijos, se iniciaban las pompas acostumbradas en las exequias, aunque la inhumación presentase múltiples variables locales y socioeconómicas. La clave radicaba en tener un 'funeral decoroso' y acorde con la 'calidad del finado', fijándose así todo el aparato: modalidad del sepelio, lugar de enterramiento, número de misas post-mortem y ofrendas.

La norma ceremonial tendía al boato y el fasto, pagándose gastos suntuosos y vanidades que no buscaban exclusivamente el beneficio espiritual de aquellos cortejos funerarios. Misas post-mortem, enterrarse en sagrado, testar, amortajarse

85 BN, Ms. 6869; Colección de Sermones de todo género y Misiones de diferentes Padres de la Compañía de Jesús, tomo I (6 $6^{\circ}$ día: “Doctrina de la confesión..., Sermón de la Muerte”, pp. 77-87).

${ }^{86}$ Bennassar, B. (1985). Los españoles. Actitudes y mentalidades. Madrid, pp. 222-230.

${ }^{87}$ Le GofF, J. (1985). El nacimiento del Purgatorio. Madrid. 
con hábitos religiosos y bulas y estar asistido en la agonía por clérigos, pobres y niños era imprescindible. Ofrendas, lutos y sepelios públicos tampoco se olvidaban. La mirada hacia lo alto se unía a la notoriedad terrena.

Desde el campanario se tañía a duelo, la vivienda, convertida en velatorio, se llenaba de gentes que veían la muerte de cerca y expresaban su 'gran opinión' y pesar, las calles pasaban a ser recintos procesionales en las que ardía la cera camino de el túmulo de enterramiento en sagrado ${ }^{88}$.

Los gastos del enterramiento y honras ejemplifican la trascendencia funeraria: religiosidad, sociabilidad clericalizada y 'gastronomía' colectiva presidían los rituales ligados a la muerte ${ }^{89}$.

"Nada de lo divino era extraño; todo era religión; la vida cotidiana respiraba actos sacros”. Y todavía las respuestas a un cuestionario de $1901^{90}$ muestran el mantenimiento de los rituales sobre "prevención, agonía, entierro, prácticas mortuorias, cementerios y culto a los muertos”. Sin embargo, según las vivencias de un cortesano portugués en el Valladolid de 1605 "las castellanas quieren ropas largas, plumas y más plumas, regalos, paseo, coches y galas; y la libertad en que se crían las hace no querer apreturas de religión" ". Apreciaba que en los actos multitudinarios "dan vueltas sin otro intento que ver y ser vistos, y distraerse. Con toda esa buhonería sale cada una el día de fiesta, que son para ellas trescientos sesenta y cinco y más las seis horas, porque ninguna pierden, ni dejan cosa en el arca que no lleven sobre sí”. Su gente "es muy amiga de llevar buena vida y de comer y vestir espléndidamente y siempre con alegría, avarientos en el adquirir y pródigos en el gastar. Viva la industria de la persona, que quien no tiene raíz fía en

\footnotetext{
88 'Cómo se han de tocar por los difuntos en sus entierros y exequias'; Constituciones Sinodales Vallisoletanas, 1604.

89 Entre otros ejemplos: ‘Gastos del Entierro’ de Juana de Zúñiga, mujer de Francisco de Valencia, Archivo Histórico Provincial de Valladolid (AHPV), Secc. Prot., leg. 284, f. 681, 1550. “Gastáronse en el enterramiento y novenario: 18 libras de cera; 18 varas de bruneta para luto de sepultura; y al cabildo 36 reales, porque le hicieron honras de beneficiado...; más lo que se gastó en dar de comer a los 32 clérigos y a los hombres y mujeres que estuvieron a las gracias: dos libras de azúcar, dos onzas de canela, un azumbre de leche, tres libras de arroz, dos libras de almendras, otras dos de pasas y dos mantequillas frescas, tres cuartillos de garbanzos, 150 huevos, tres libras de manteca de burras, otras tres de aceite, un azumbre de miel, tres quesos frescos y uno añejo, catorce libras de peros, ocho libras de pescado cecial bueno seco, seis de congrio cecial, siete cántaras de vino y tres fanegas de trigo".

90 Cuestionario-Encuesta del Ateneo, 1901-1902. En Valladolid, la Encuesta sólo fue respondida por: Medina de Rioseco, Medina del Campo, Villabrágima, Nava del Rey, Tordesillas, Villavaquerín y Valladolid ciudad.

${ }^{91}$ Pinheiro Da Veiga, T. (1973). Fastiginia o Fastos geniales. facsímil, Valladolid, p. 304.
} 
Dios y busca remedio, y él no falta, que no faltó a mis dueños ni ha de faltar a mis nietos; y si no, a morir a Flandes, y no cavar viña con los ganapanes. Y así, las mujeres siguen la misma ley, y su Dios su gusto, no perder domingo sin huerta, ni huerta sin merienda, y ahórquese el diablo"92.

92 Ibídem, pp. 54-57, 299-300 y 309-310. 